\title{
واقع العلاقات التركية الألمانية والبحث عن نموذج للاستقرار
}

د. دامر علي راضي العلاق

وزارة التعليم العالي والبحث العلمي لعي لعي

مقدمة

لاشك أن الدول تتحرك حيال غيرها بصيغ علاقات التعاون أو الصراع تبعاً

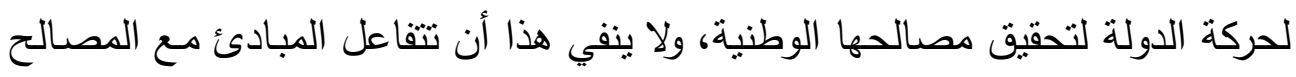

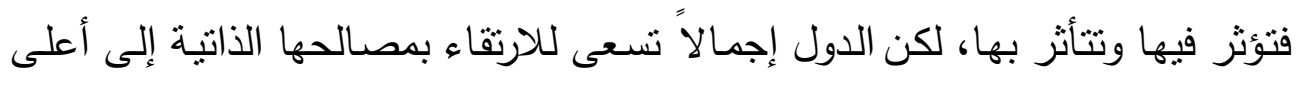

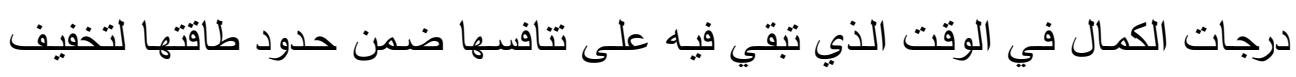

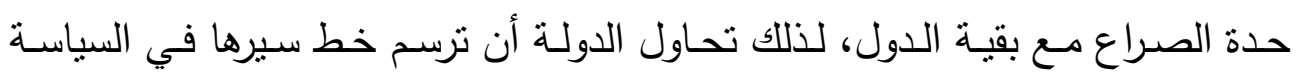

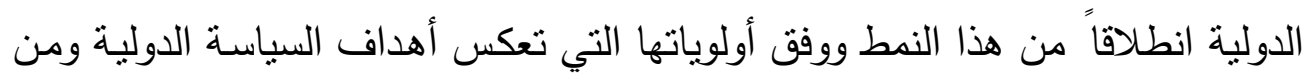

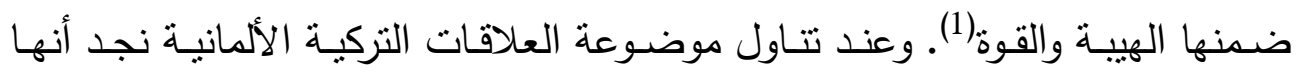

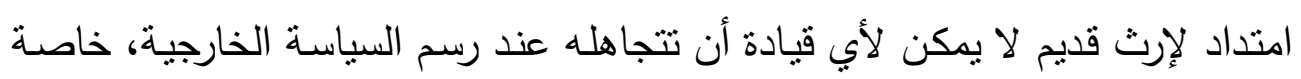

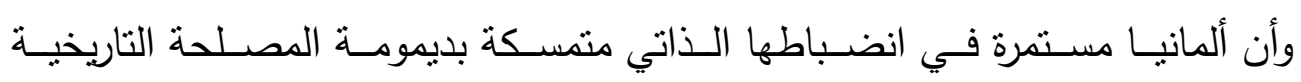
والعلاقات الخاصة مع تركيا. أهمبة الدراسة

تأتي أهميـة هذه الدراسـة من كونها تتطرق لموضوعة حيويـة في العلاقات

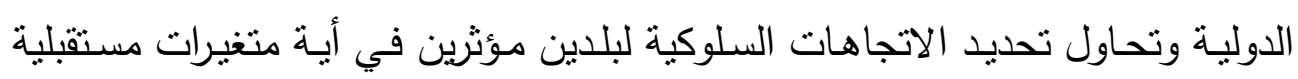

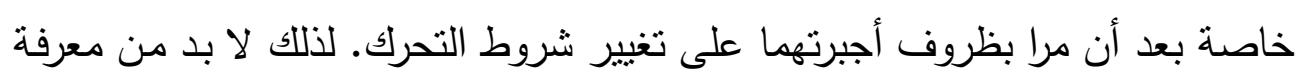

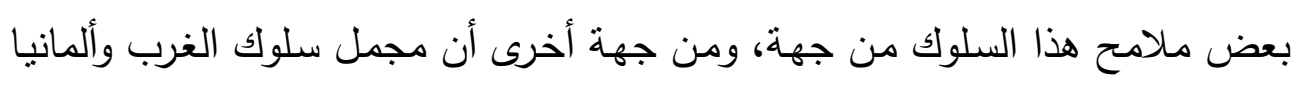

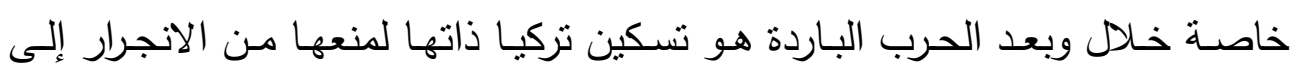
أفعال سلوكية قد تضر بأوربا. فرضبة الاراسة 
تحاول هذه الدراسة التحقق من الفرضيات التالية:

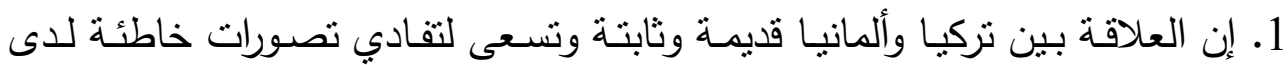
الجانبين حول مصالح وأهمية الطرف الآخر .

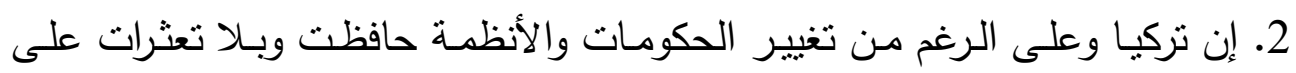
علاقاتها التحالفية الغربية. إن من مصلحة ألمانيا جعل تركيا منيعة ضد انتقال عدوى العنف والحفاظ على دورها الراهن غير السلبي واستمرار توجها السياسي الغربي العام، والحيلولة دون تحولها إلى تهى

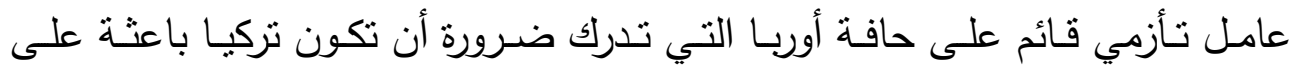
الاستقرار في نقطة الاشتعال بين مناطق الأزمات المختلفة.

مشكبة الإراسة

إن العلاقـة التركيـة الألمانيـة تمثنل العمـود الفقري لعلاقـات تركيـا مـع أوربـا،

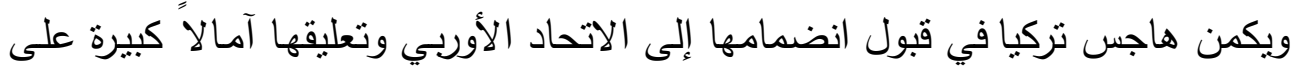
دعم ألمانيا لها في هذا الثأن، إلا أن هذه الآمال غالباً ما تتبدد بفعل متغيرات الوضع

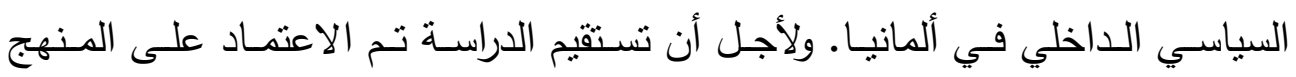
التاريخي لمعرفـة العوامـل المحركة لهذه العلاقـة وعلى المـنهج الوصـفي والتحليلي، ولأجله سوف نتتاول المواضيع التالية:

$$
\begin{aligned}
& \text { 1- الجذور التاريخية للعلاقات التركية-الألمانية. } \\
& \text { 2- تركيا في الإدراك الأوربي والألماني. } \\
& \text { 3- الرؤى المشتركة ومجالات التعاون بين تركيا وألمانيا. } \\
& \text { 4- الرؤى والمحاور المتأرجحة بين البلدين. }
\end{aligned}
$$

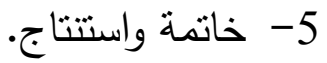

\section{1. الجذور التاريخية للعلاقات التركية-الألمانية:}

تعـد العلاقــة بـين نركيـا وألمانيـا مـن العلاقـات العربقـة، فالعالمـان العثــاني والجرماني تولجها منذ القرن السادس عشر فارضين تقسيماً ضمنياً على أوربا الوسطى لردي 
والثرقية كما في البلقان ثم تحولت هذه المواجهة إلى تحالف، وتمثل هذه العلاقة في

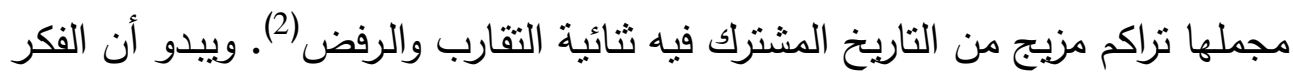

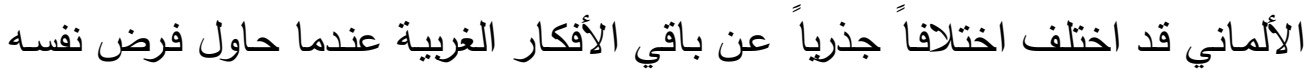
على الدولـة العثمانيـة كمستثمر اقتصـادي وليس كمستعمر سياسي، حيث توجهت

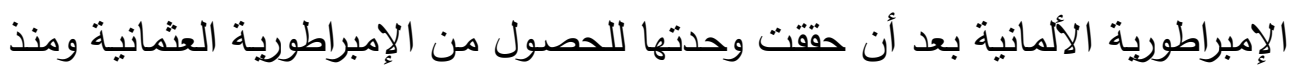

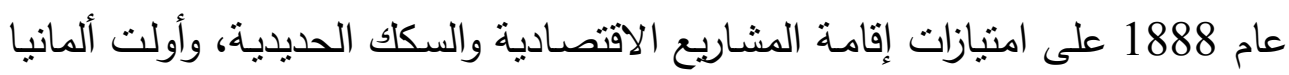

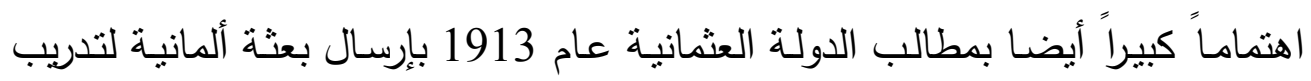

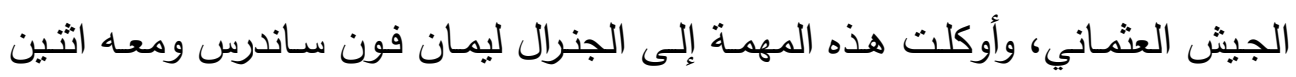

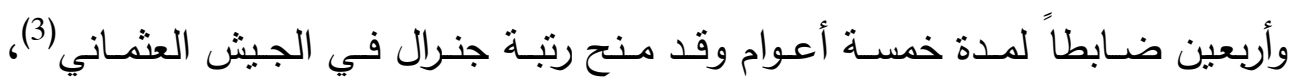

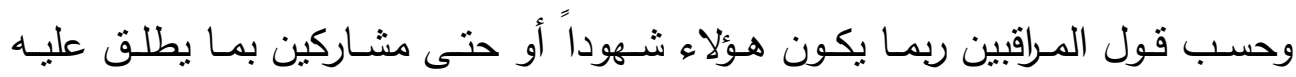

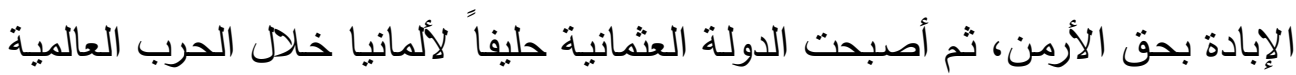

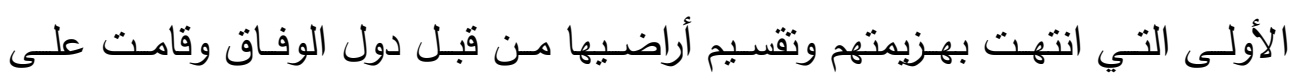

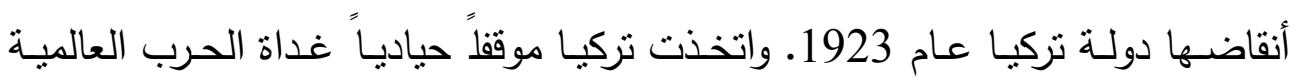

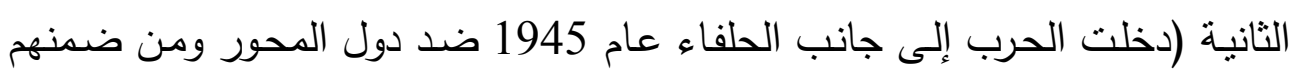

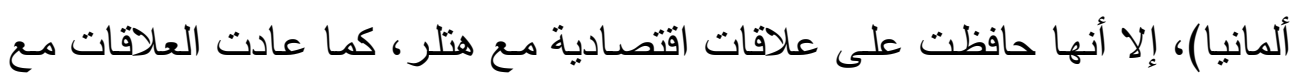

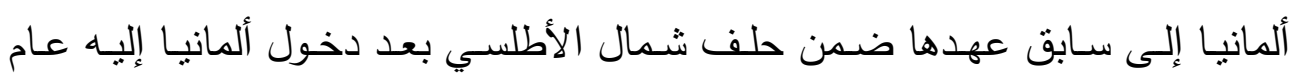

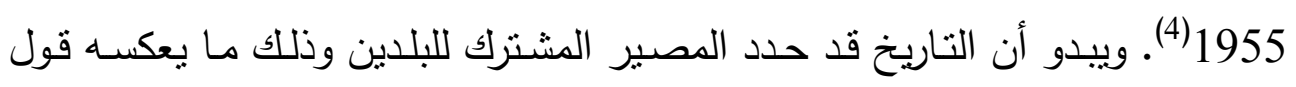

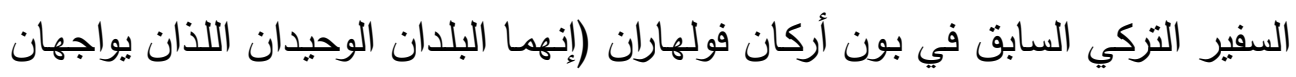

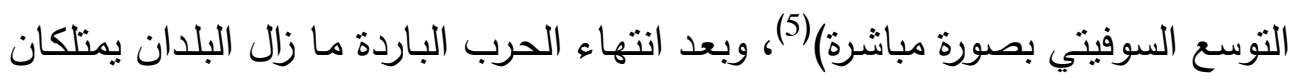
القوة والعزيمة للقيام بالدور الذي خصتهم به الجغرافيا. 2. تركيا في الإدرالك الأونبي والألماني

لقد سعت تركيا في حركتها الدولية للابتعاد عن الثرق ولم تعد تتظر لـه إلا

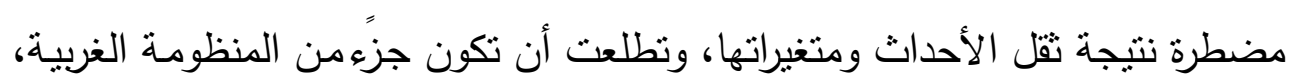

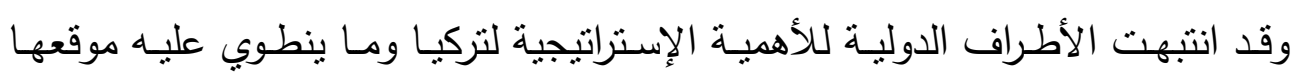

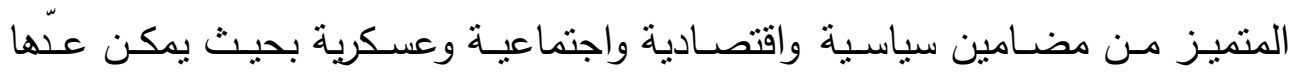


المفتاح الجيوبولتيكي لعموم المنطقة بحكم إطلالتها على نقاط الفعل الدولي والتأثثر

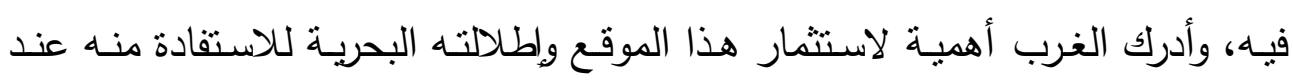

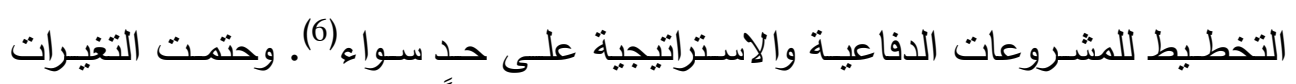

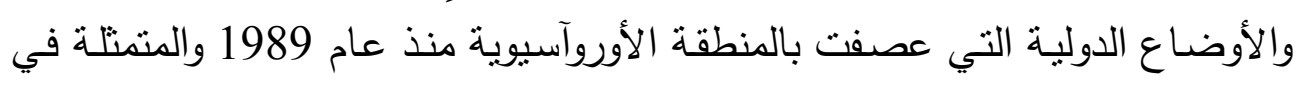

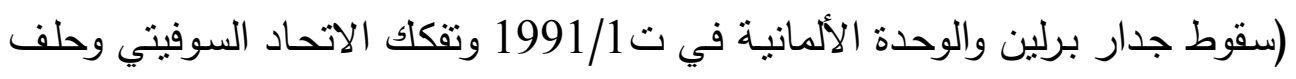

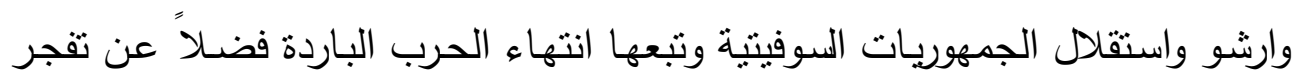

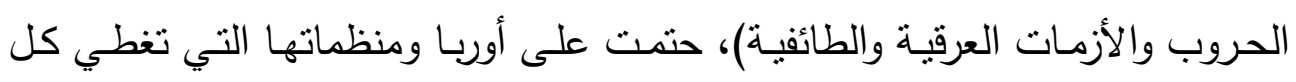

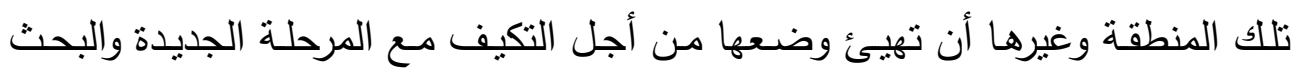

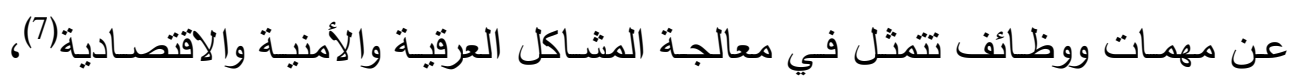

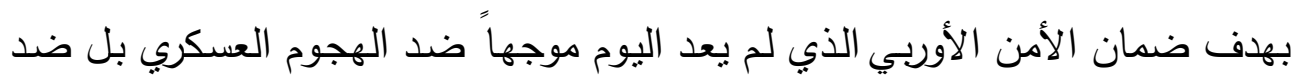

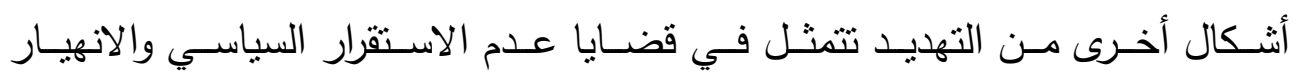

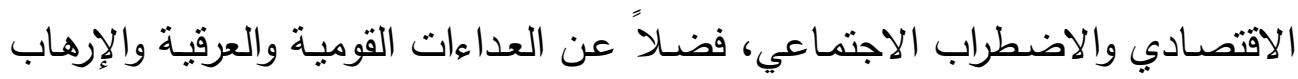

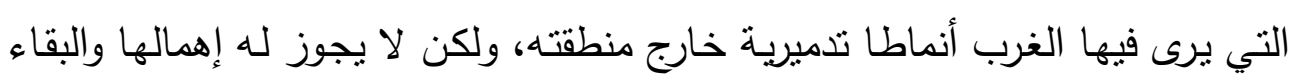

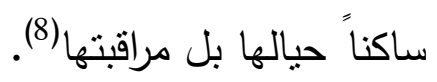
وتتمركز هذه التحديات في نطاق قوسين للأزمات أحدهما القوس الثرقي

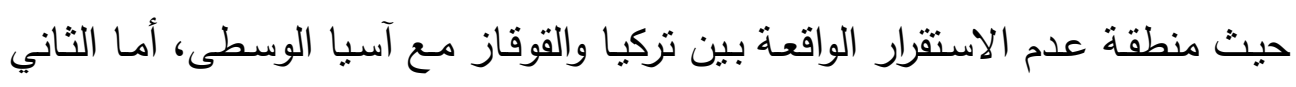

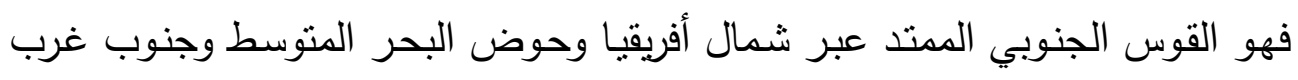

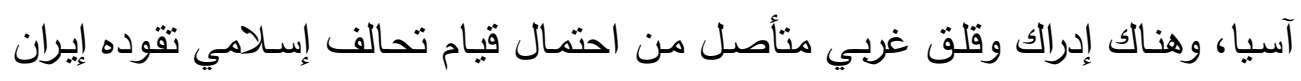

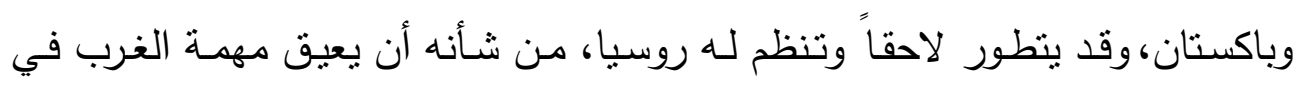

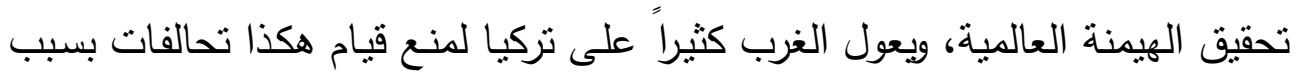

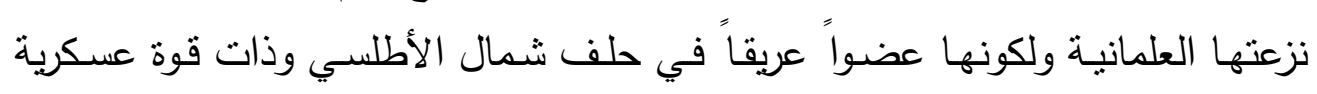

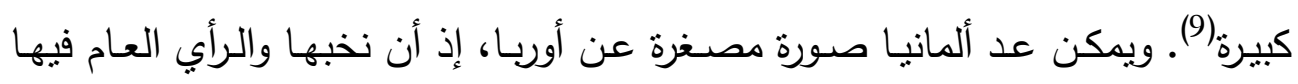

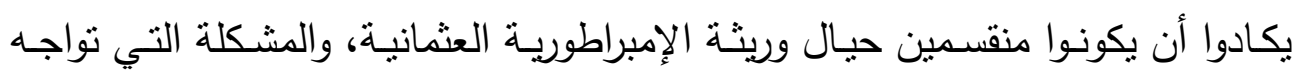

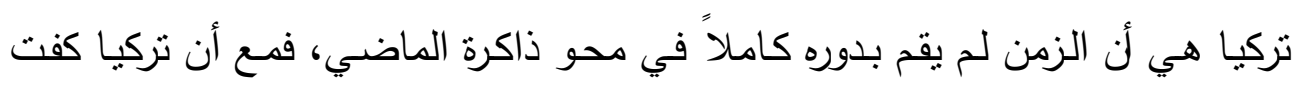

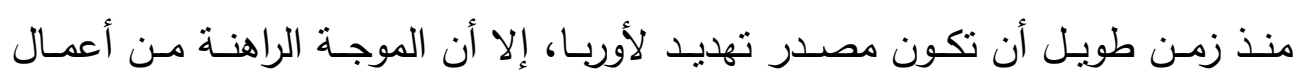


الإرهاب التي ترفع رايات إسلامية أحيت في الذاكرة الأوربية التطابق القديم بين تركيا

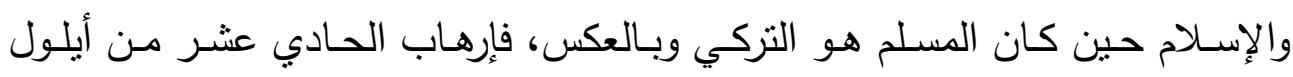
2001 وتقجير قطارات مدريد وتقجيرات لندن 2005 ومشاهد اختطاف الرهائن وجز الرؤوس في العراق وغيرها من الأحداث، جدد في الذاكرة الأوربية المخاوف من تركيات

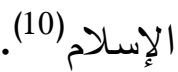

ولكن من جانب آخر وعند تأمل النظرة الأوربية الإيجابية لتركبا، يبدو أن أهم

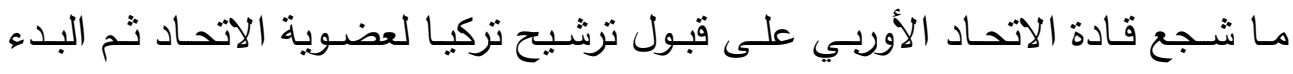
بمفاوضـات العضــية في ت2005/1، التجربـة الفريـدة التـي تقـدمها تركيـا للعـالم

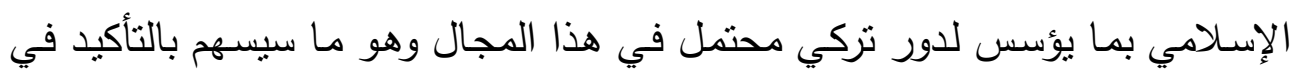

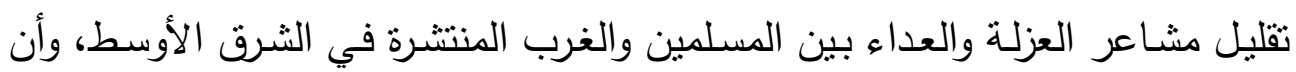

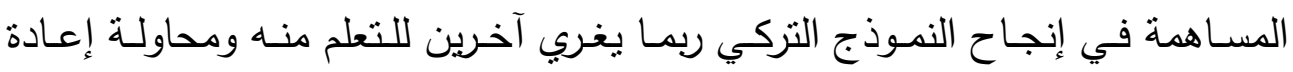

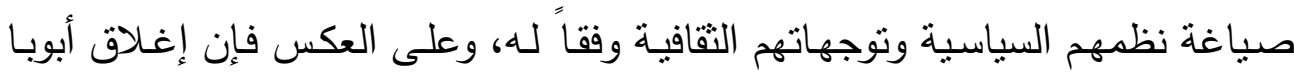

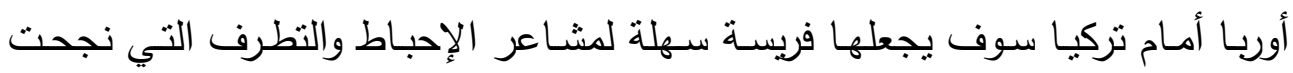

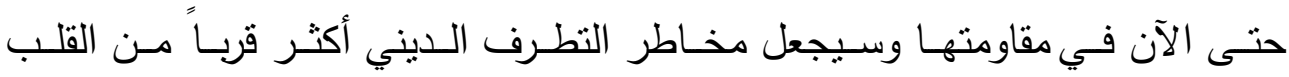

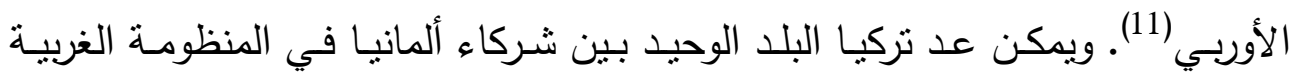

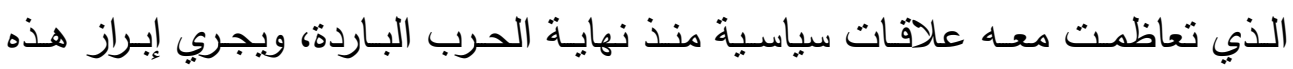

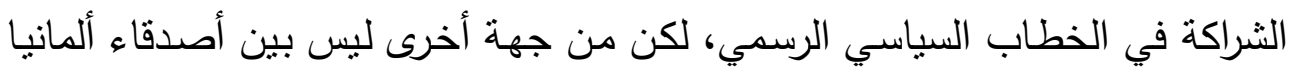

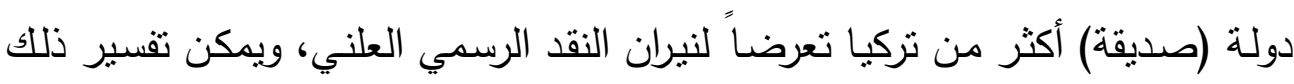

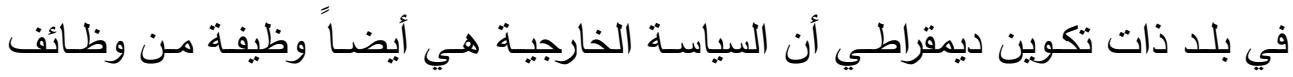

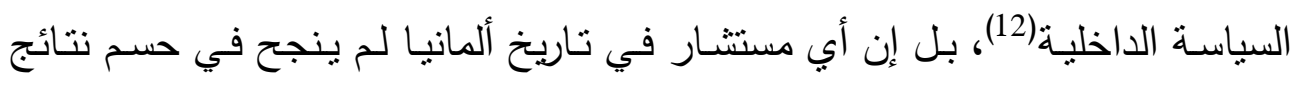

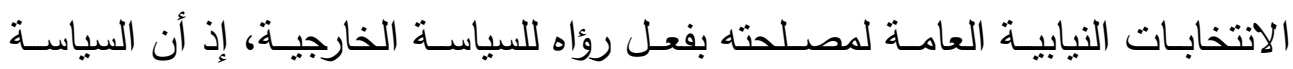

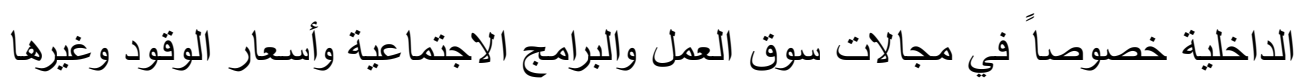
من أهم عناصر البرامج الانتخابية المؤثرة في مزاج جمهور الناخبين الألمان (13)، ولأن

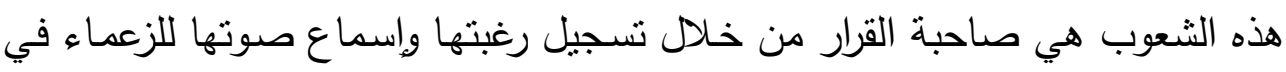
الانتخابات. وقد أكد المستثار الألماني السابق غيرهارد شرودر النظرة الألمانية العامة 
حيال تركيا في سياق النقويم الجديد الذي أجراه لتأثير تركيا المحتمل في منطقة ذات

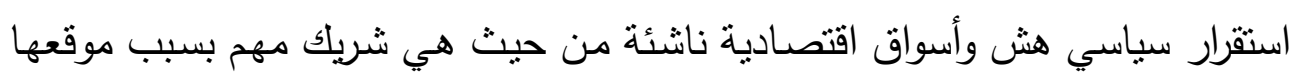
الجيوبولتيكي، وأنها تمنل سوقاً اقتصادية واعدة ومنطقة قابلة للاستثمار المتزايد فضـالًا

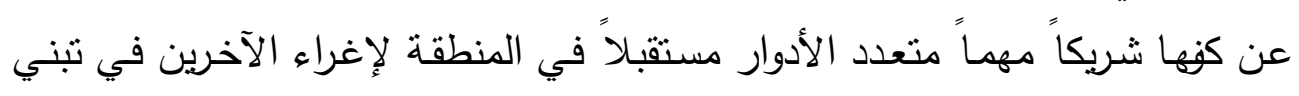

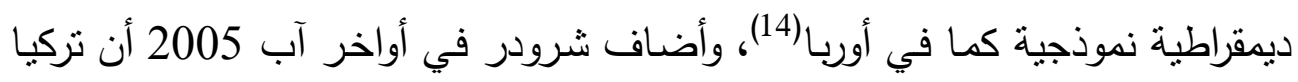

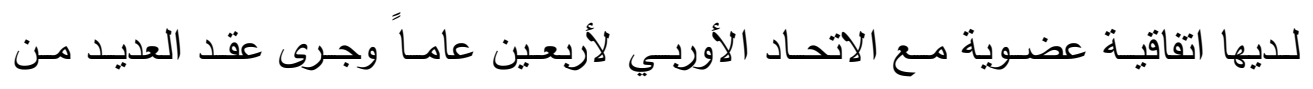

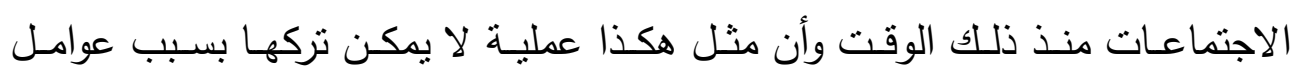

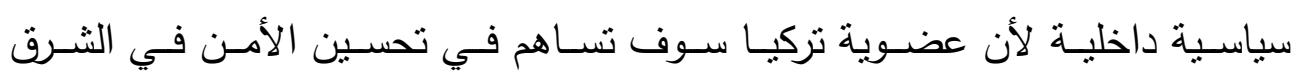

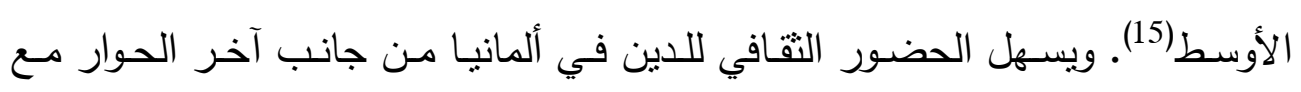

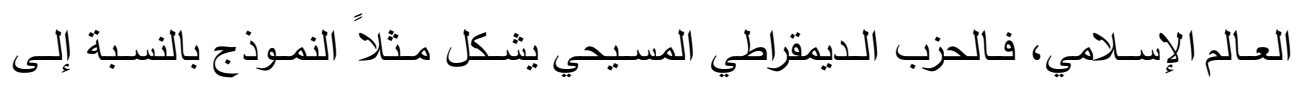

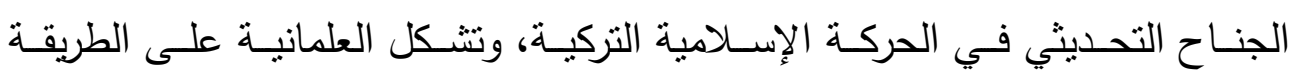

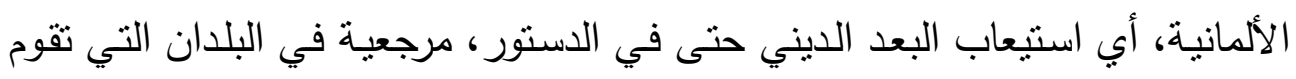
فيها الحريات على نوع من العلاقة بين الدين والسياسة (16).

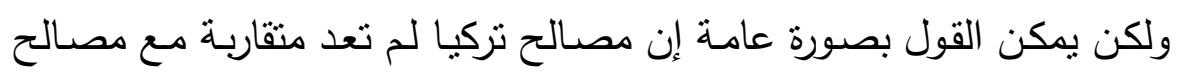

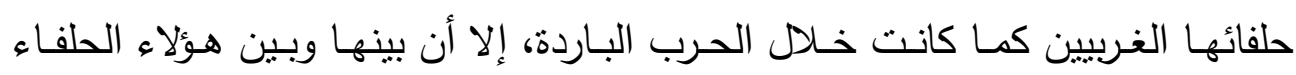

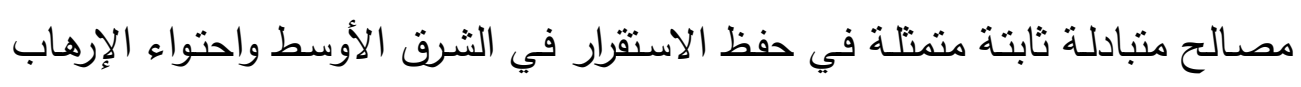

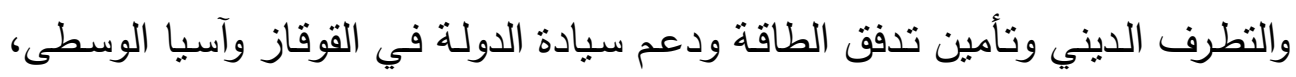

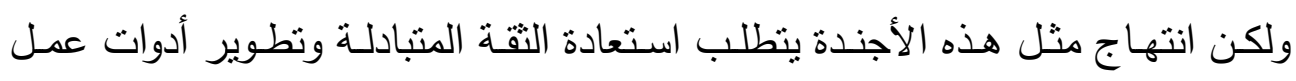

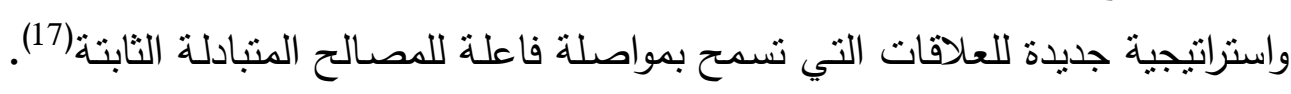

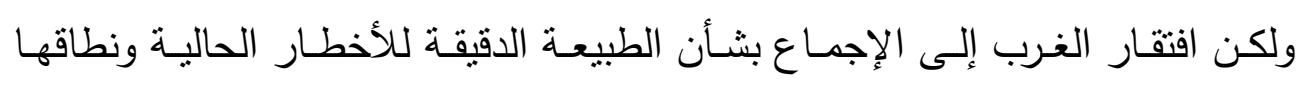

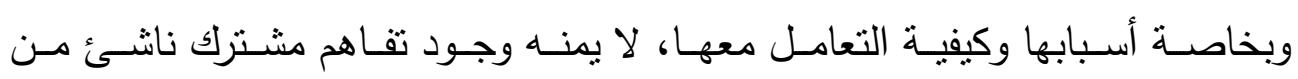

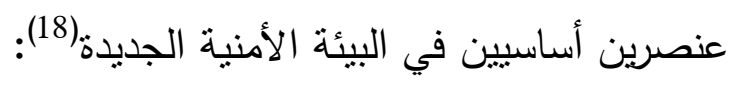

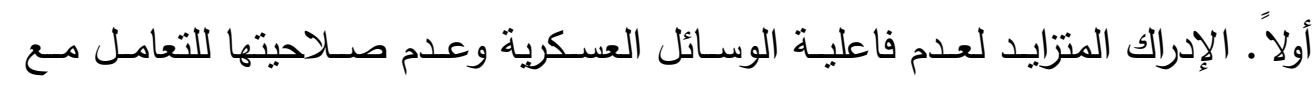

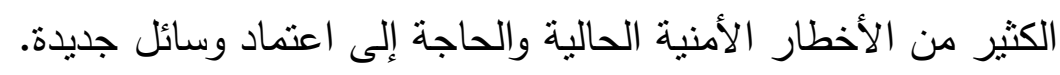


ثانياً. الإقرار بالطبيعة العالمية للأمن وأن الثمال أصبح على وجه الخصوص أكثر الثبر

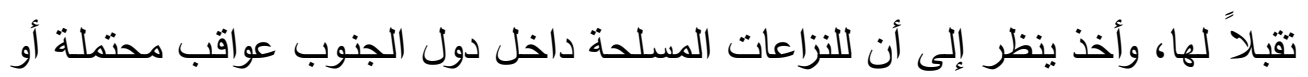

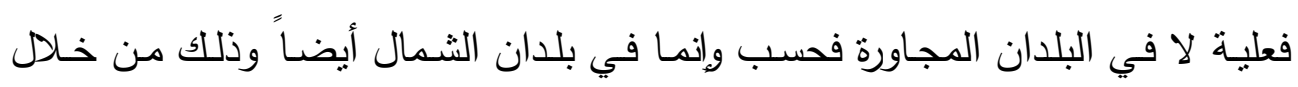
تهريب الحخدرات وتدفق اللاجئين وغيرها، ولغرض الحصر فإن تركيا تشكل بلد مرور

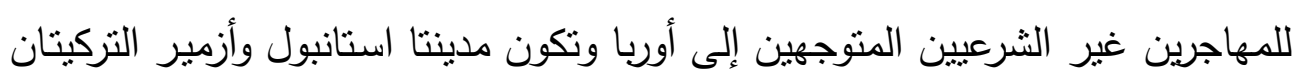

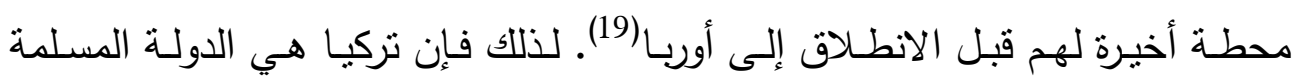

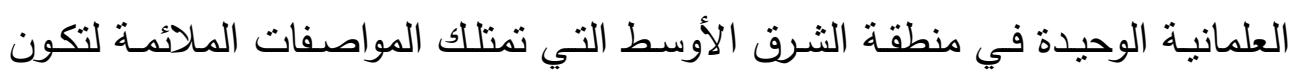

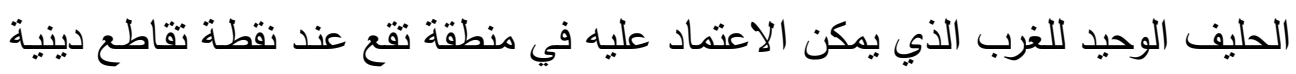

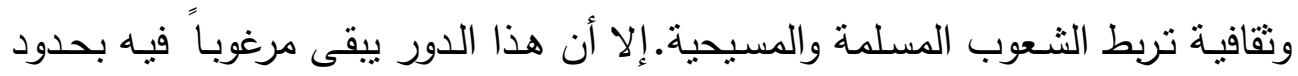
معينة ترتبط بـ (20):

1- مواجهة التحدي الأصولي أينما وجد في المحيط الداخلي.

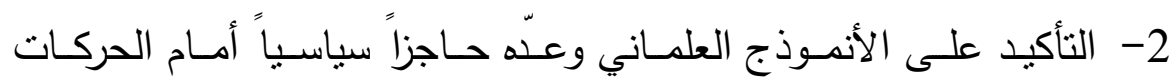

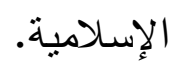

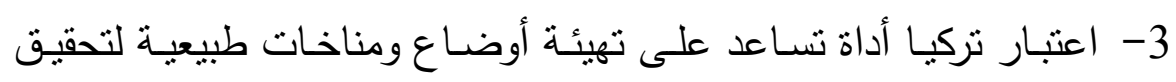

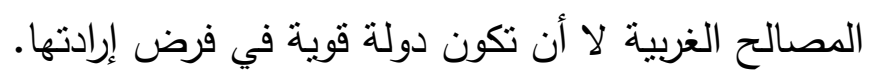

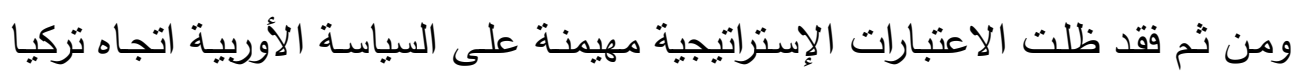

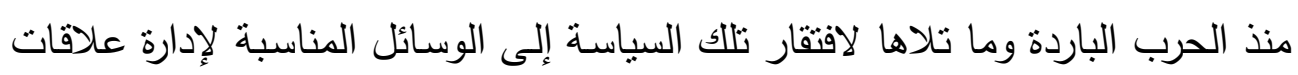

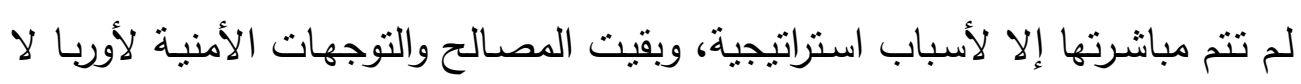

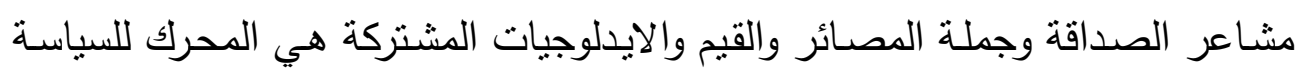

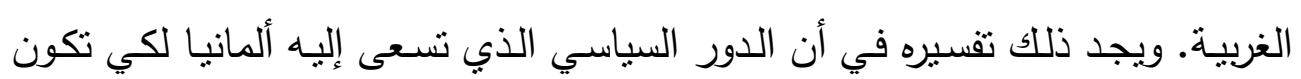

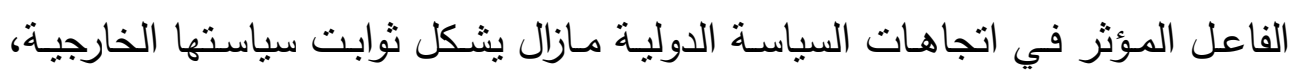

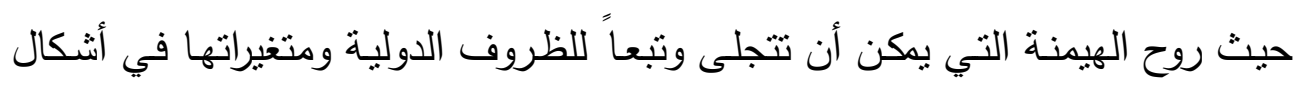

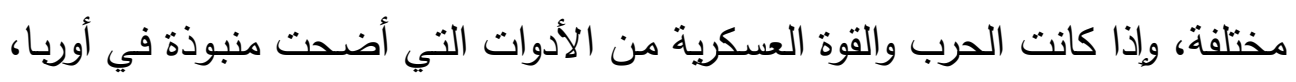

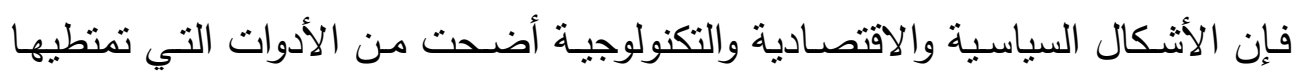




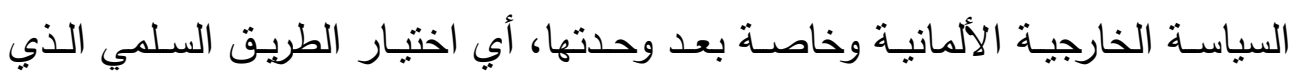
يعزز من أسس ومرتكزات الأمن والاستقرار في أوربا(21).

\section{3. الرؤى المشتركة ومجالات التعاون بين تركيا وألمانيا}

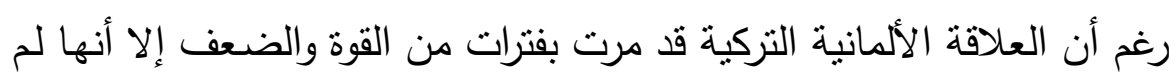

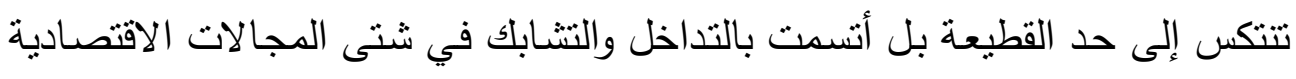

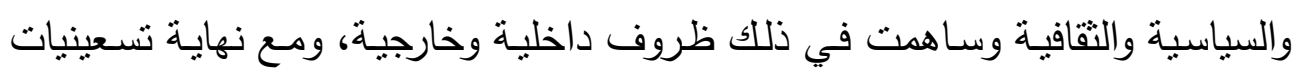

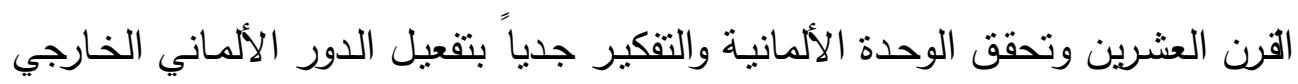

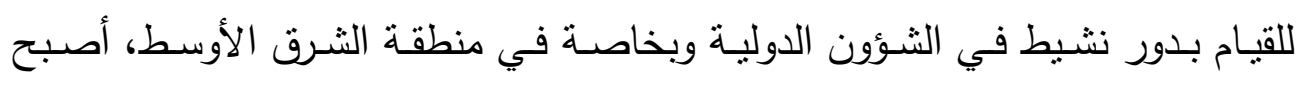

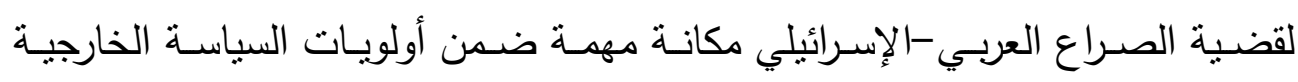

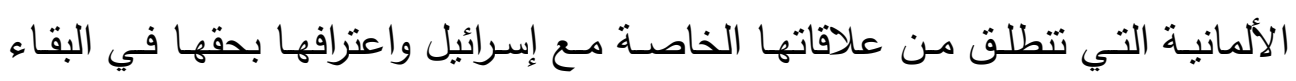

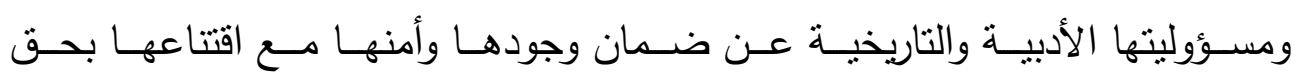

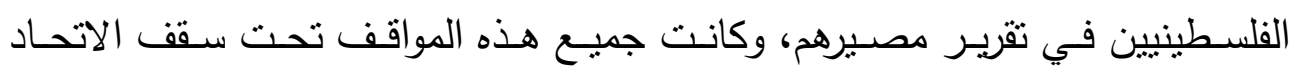

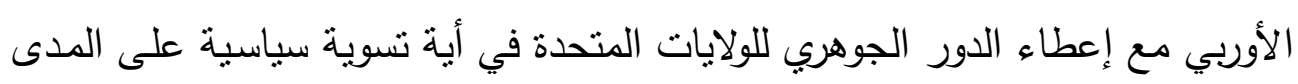

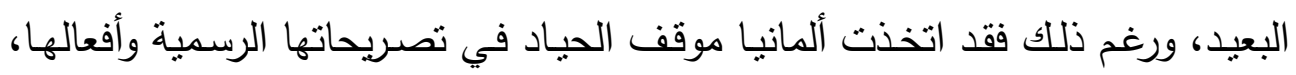

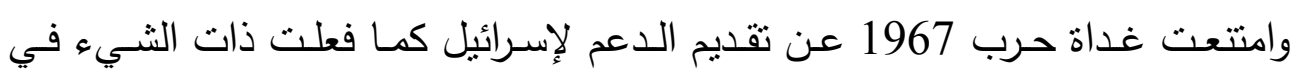

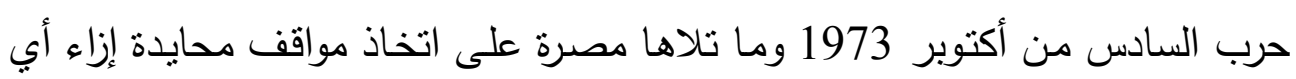

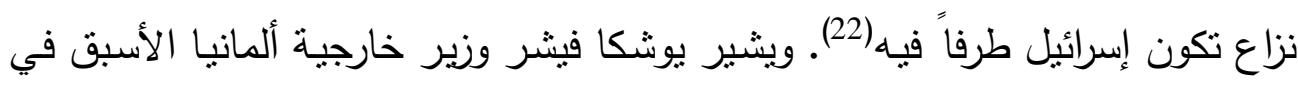

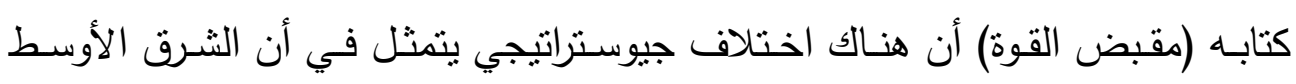

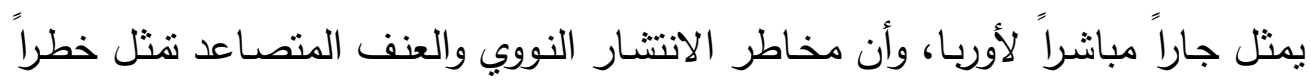

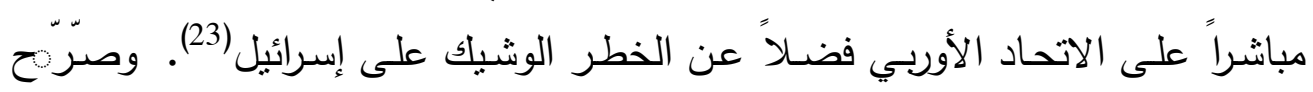

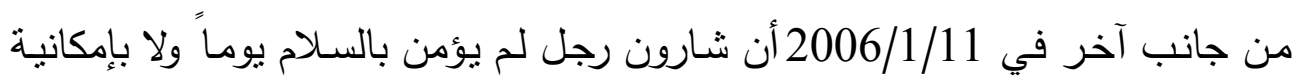

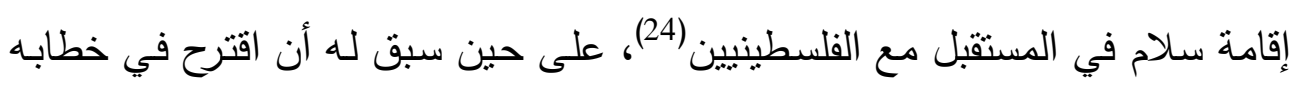

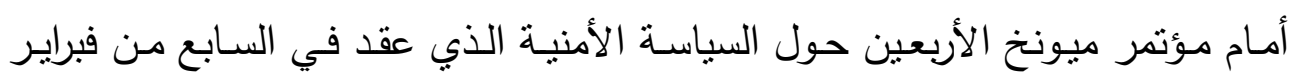

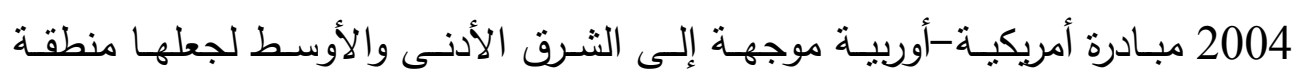


تجارية وارساء الديمقراطية ودولة القانون والتخلي عن العنف. ويرى فيشر أن الفشل

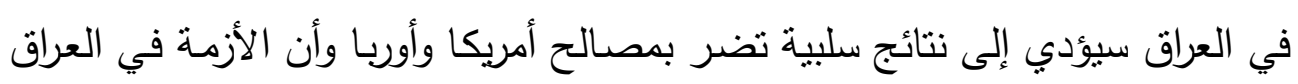

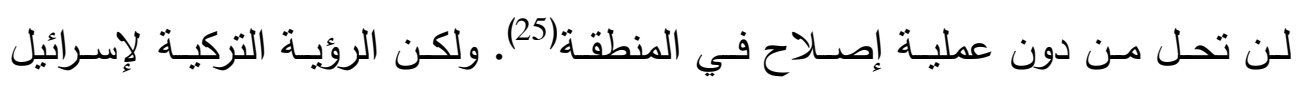

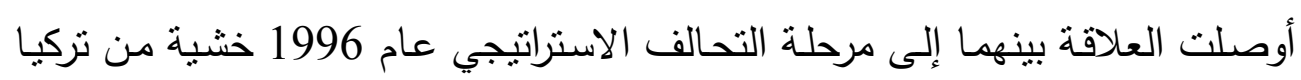

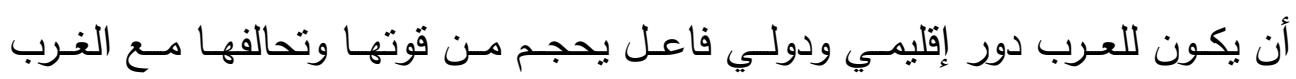

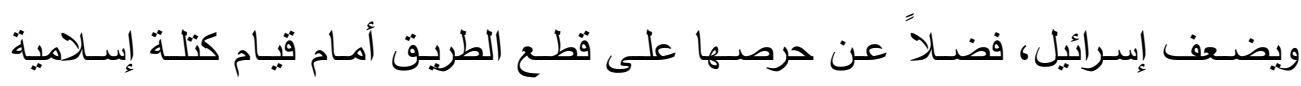

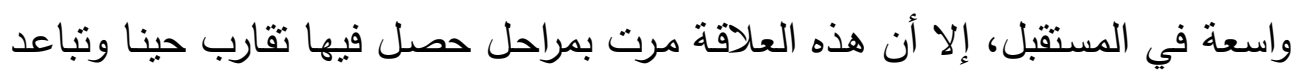

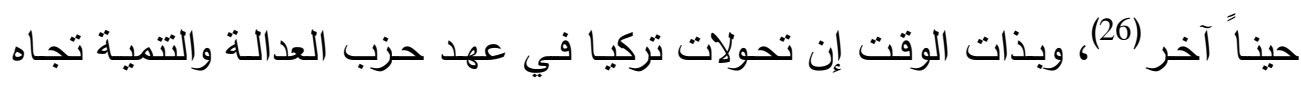

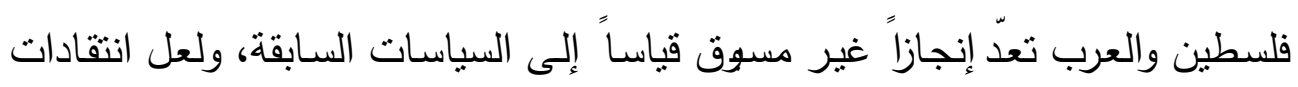

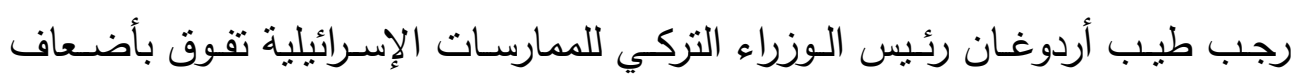

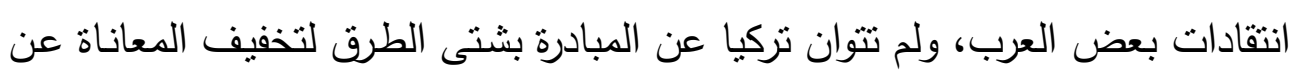

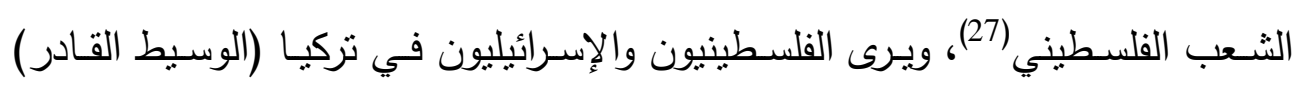

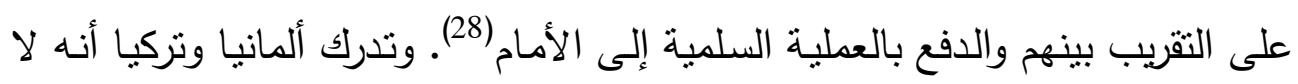

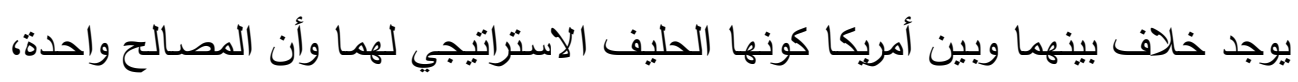

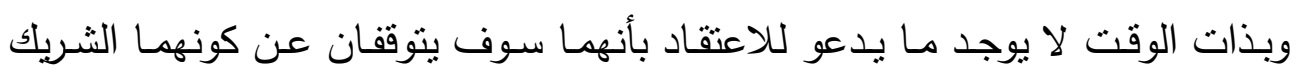

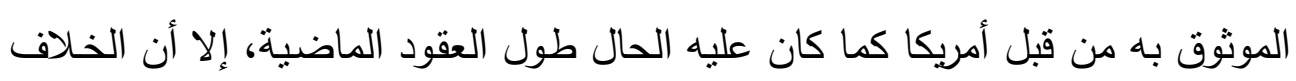

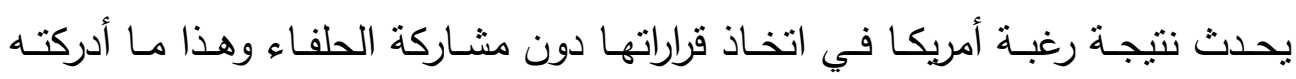
الولايات المتحدة وعملت على تلافيه فيما بعد (29).

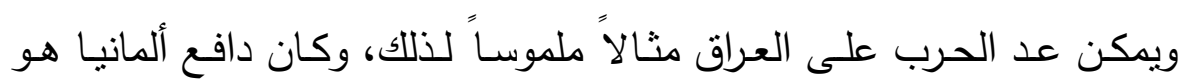

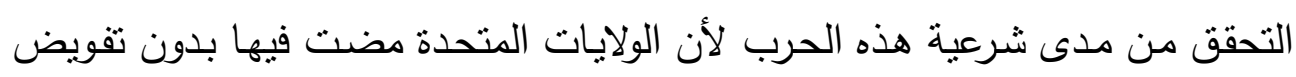

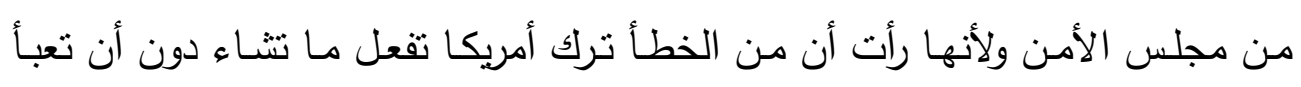

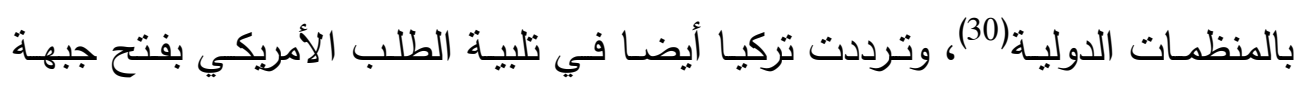

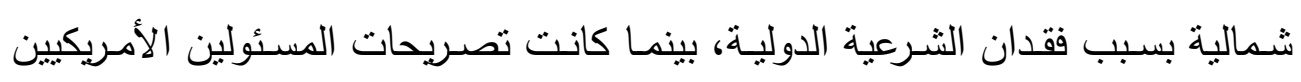

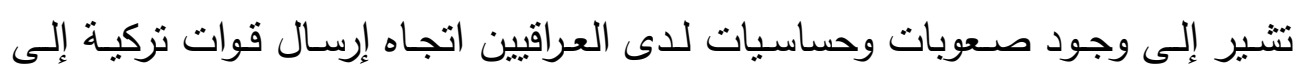
العراق (31)، ولكن بعد احتال العراق في 9 نيسـان 2003 سمحت العكومـة التركيـة 
برئاسة رجب طيب أردوغان بتمرير الإمدادات العسكرية إلى قوات الاحتلال من شمال

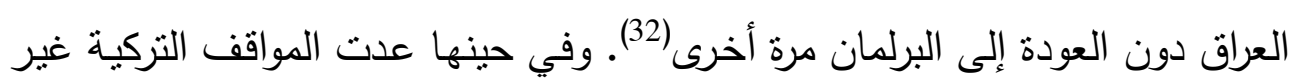

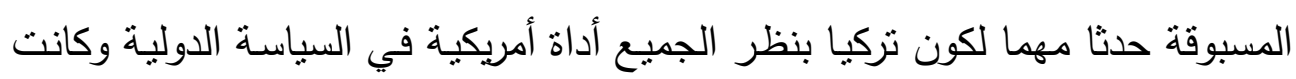

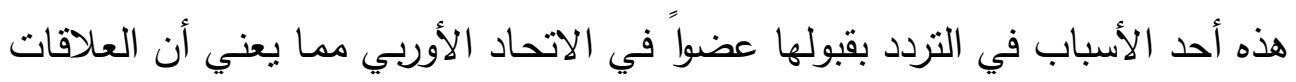

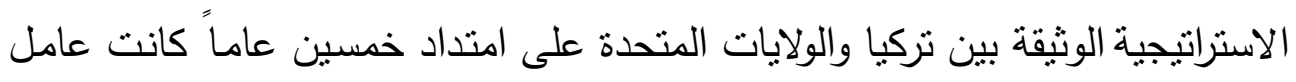

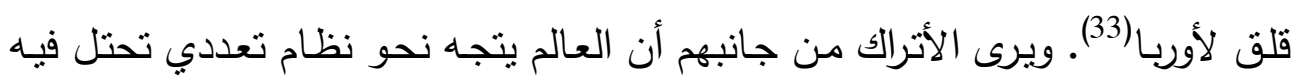

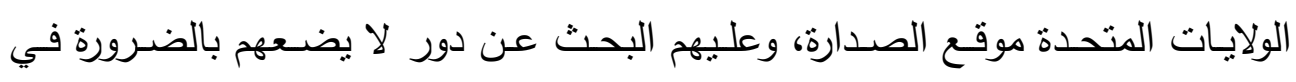

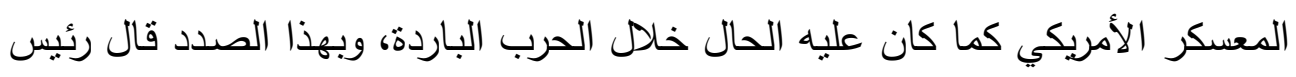

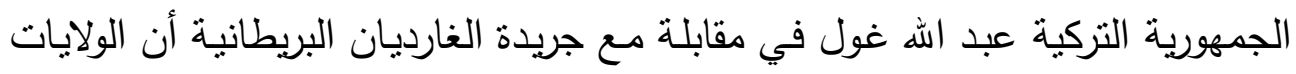

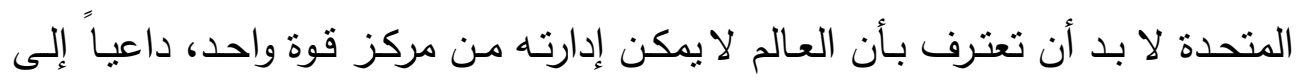

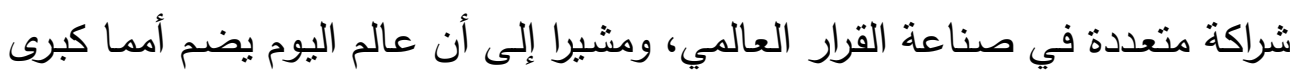

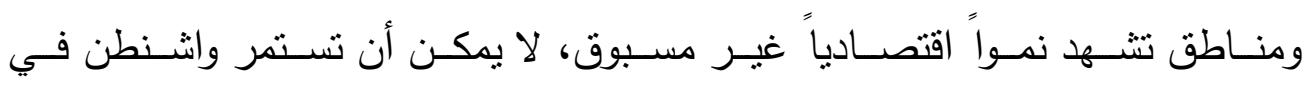
تجاهلها(34). ولم تخرج تركيا من مرحلة الحرب الباردة بقدر كاف من الأمن والطمأنينة

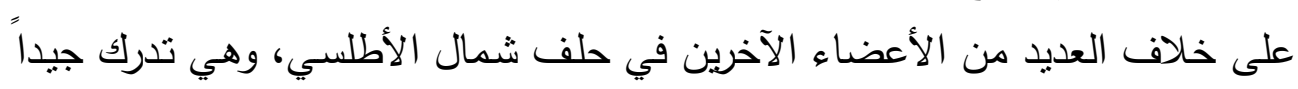

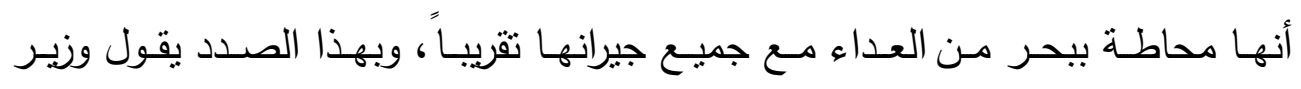
خارجية تركيا السابق حكمت تثتنين عام 1993 (لقد تحولت تركيا إلى دولة مواجهة

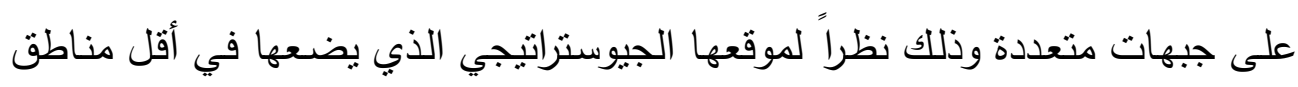

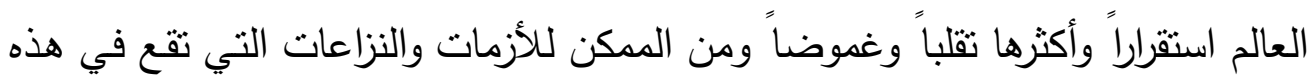

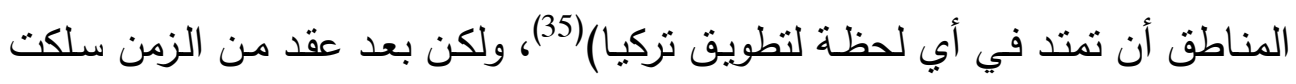

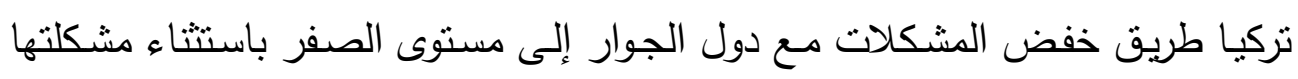

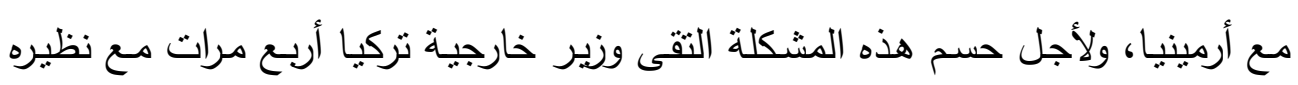

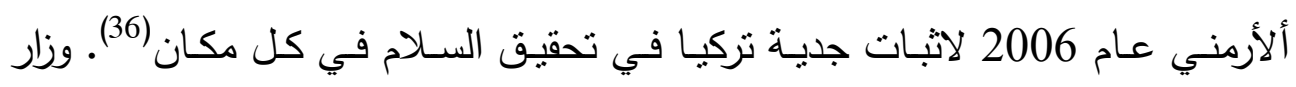

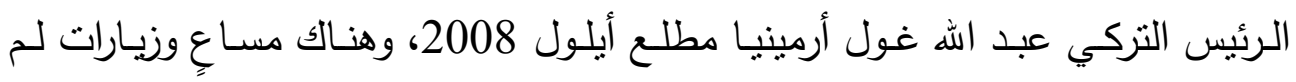
تتقطع لنقريب وجهات النظر ، حيث رفضت تركيا إقامة علاقات دبلوماسية مع أرمينيا 


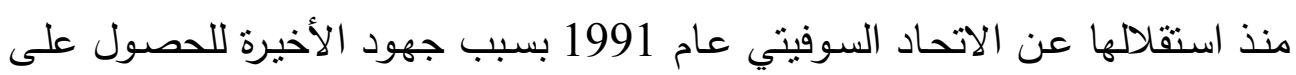
اعتراف دولي بمذابح الأرمن التي جرت أبان الحكم العثماني (37).

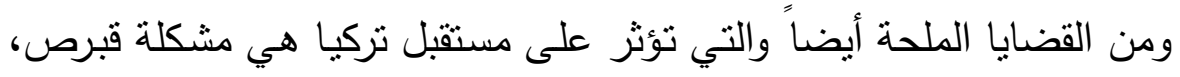

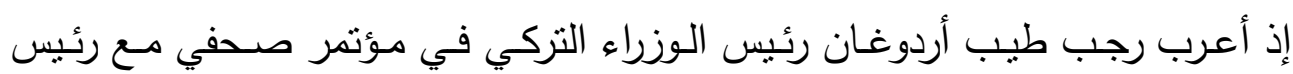

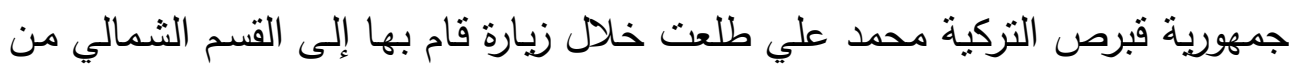
الجزيرة منتصف تموز 2008 عن تفاؤله بقرب إطلاق مفاوضات شاملة لإعادة نوحيد

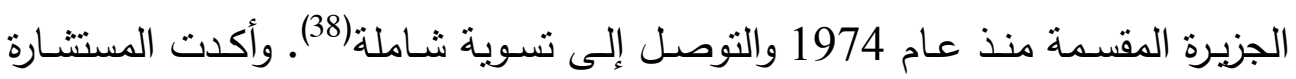

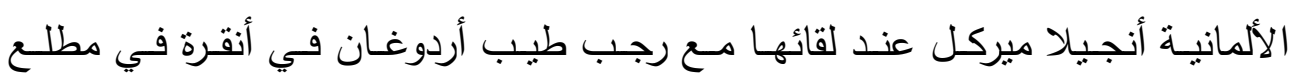

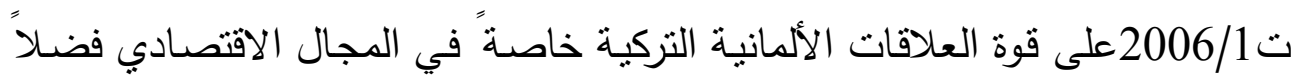

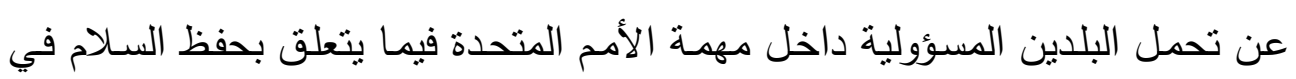

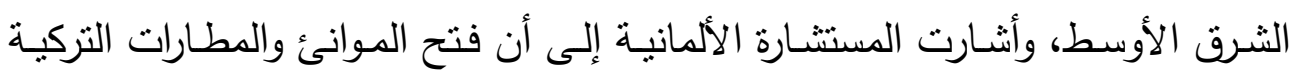

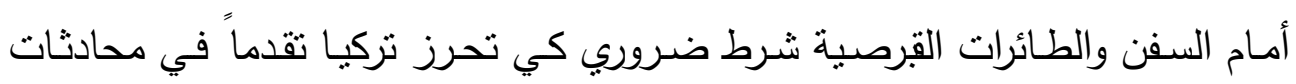

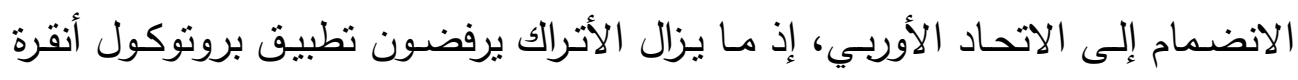

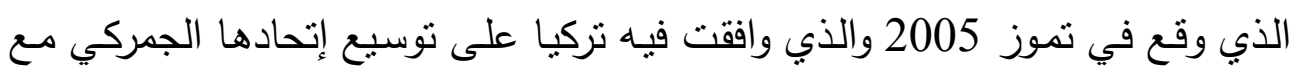
الاتحساد الأوربي ليشمل الدول العشر التي انضمت إلى الاتحاد عام 2004 وبينها

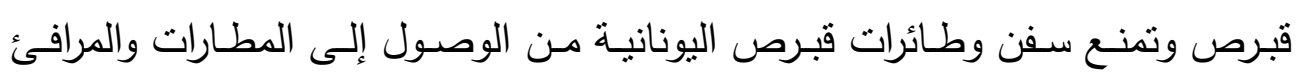
التركية(39).

وتعد تركيا الدولة اليوم الراعية لحل أهم وأعقد مشكلة في الدنطقة، إذ تجري

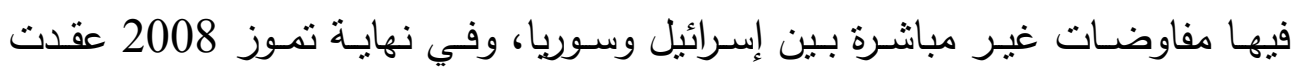

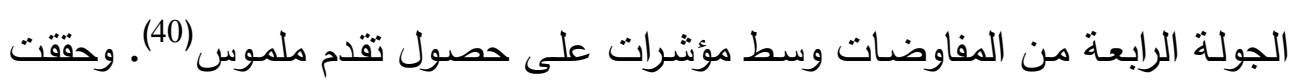

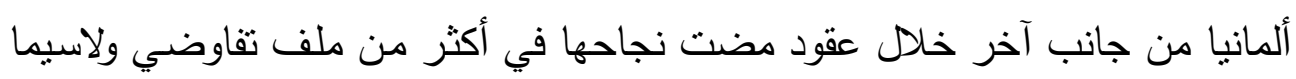

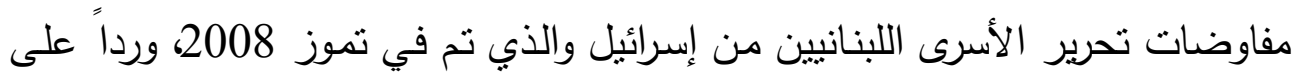

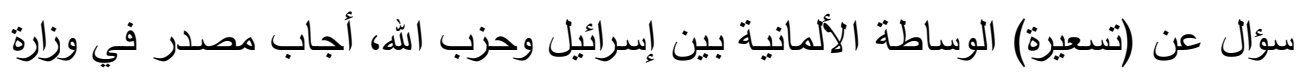

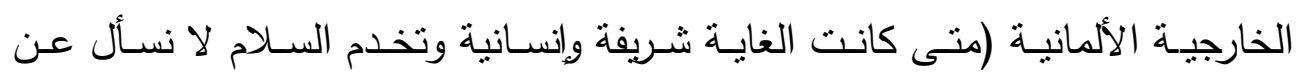
التكاليف)(41). وأكد وزير خارجية نركيا علي باباجان في منتصف تموز 2008 (أن 
إيران والدول الست المعنية بمفاوضـات الملف النووي الإيراني طلبت مساعدة تركيا

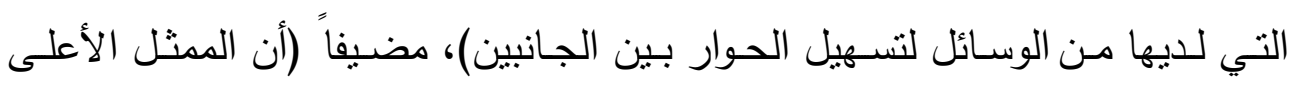

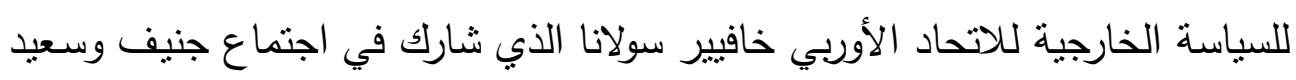

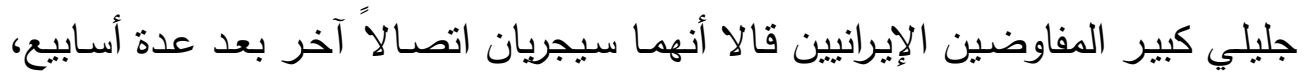

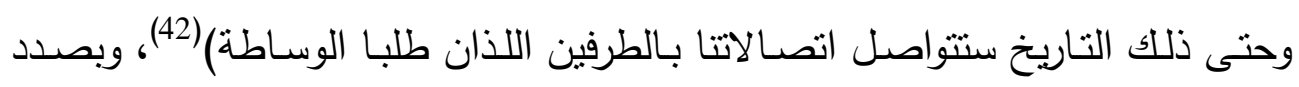

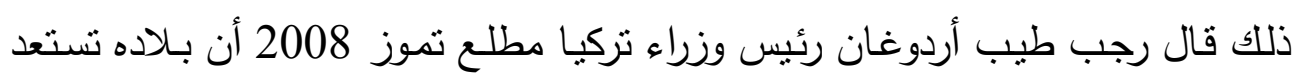

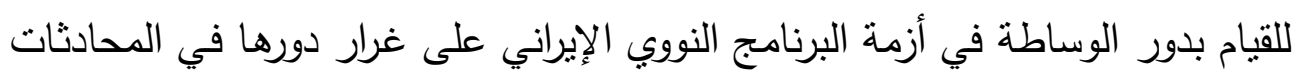

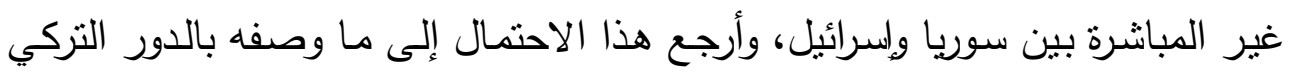

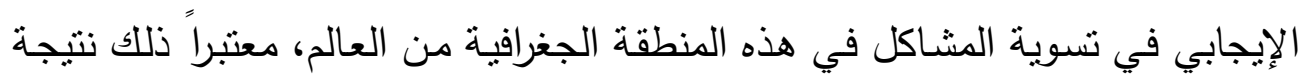

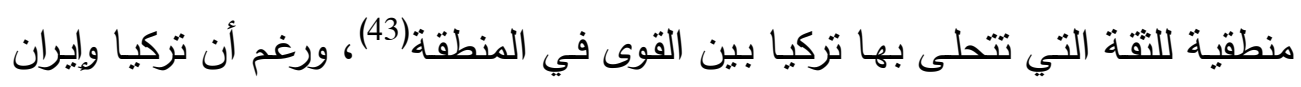

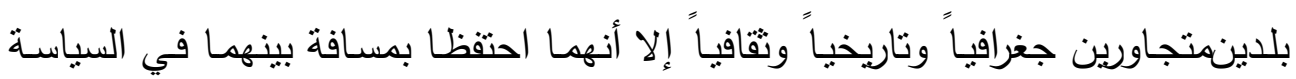

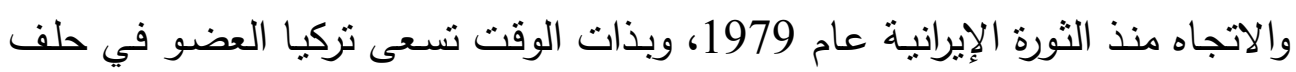

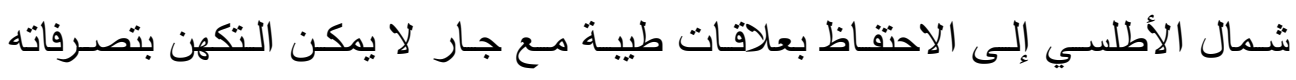

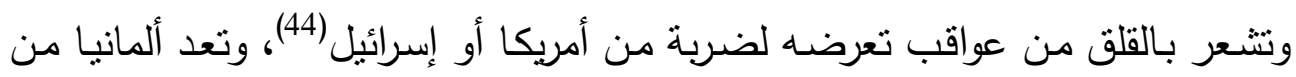

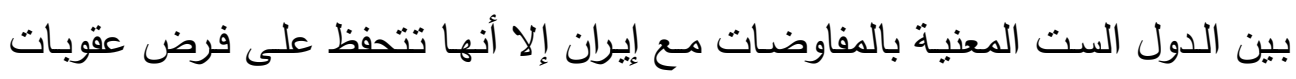

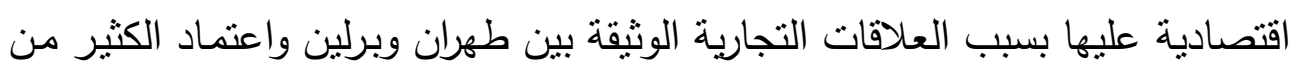
الثركات الكبرى في ألمانيا على العلاقات الاقتصادية مع إيران (45).

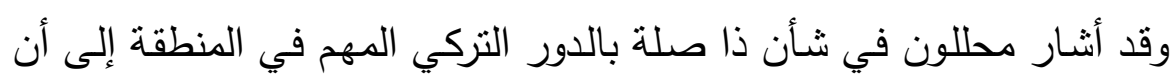

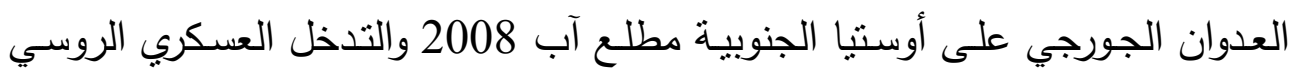

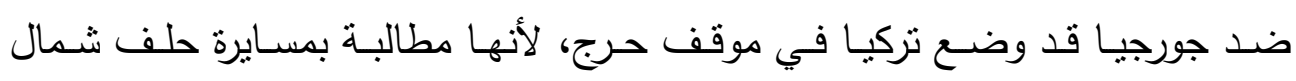

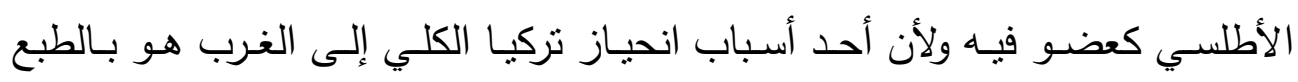

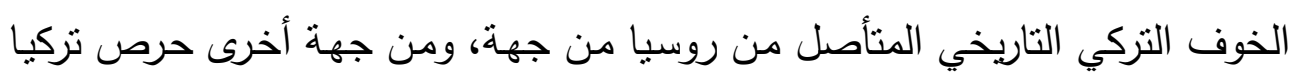

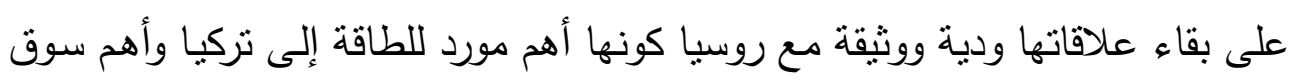

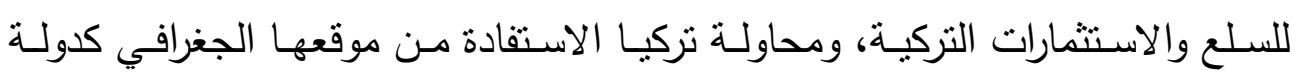

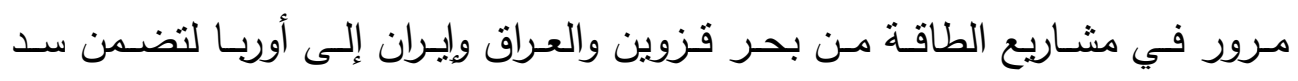




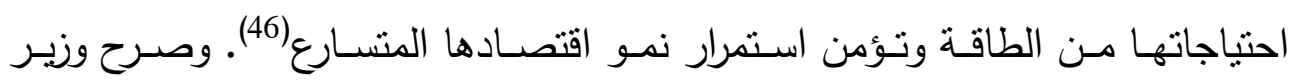

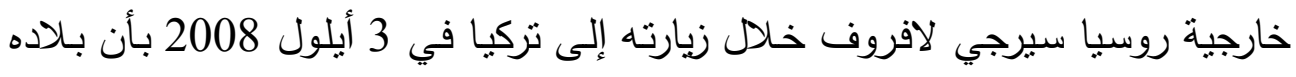

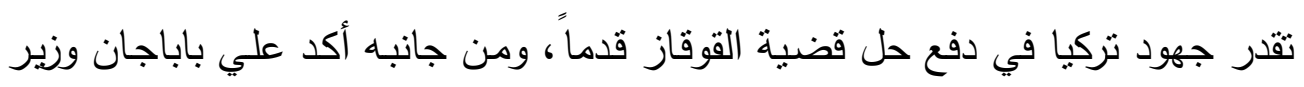

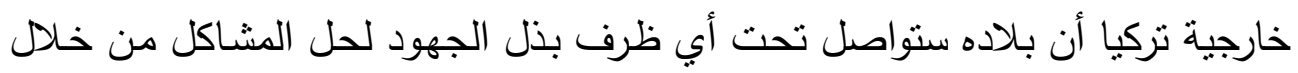

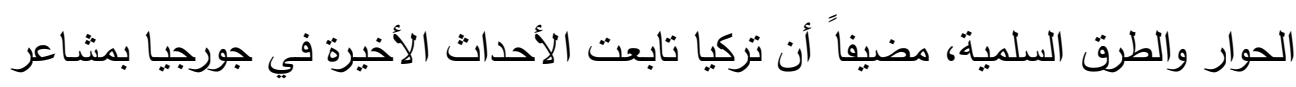

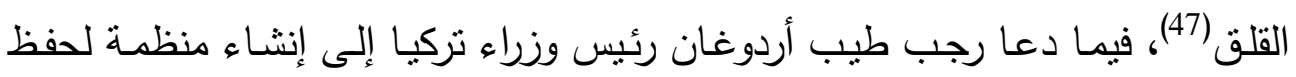

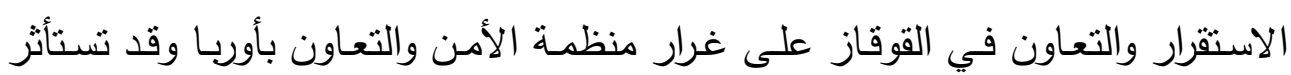
هذه المبادرة باهتمام روسيا (48). على حين قالت المستشـارة الالمانيـة خـلال زيارتها إلى جورجيـا خـلال هذهـ

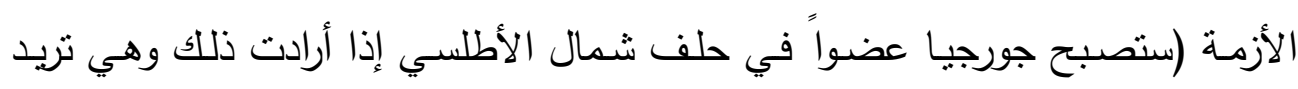

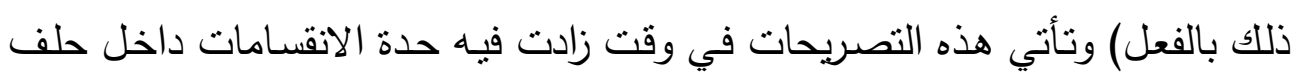

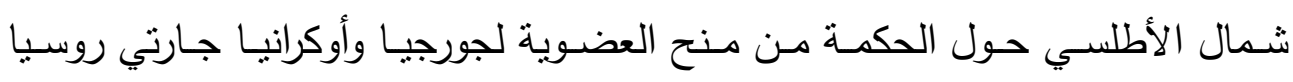
والخلافات داخل أوربا بشأن كيفية التعامل مع روسيال (49).

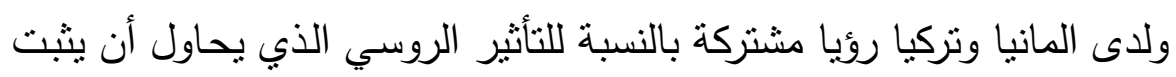

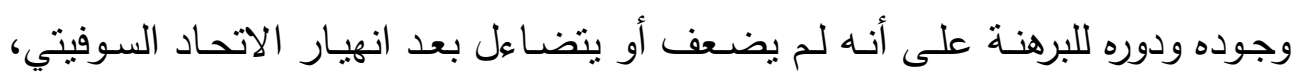

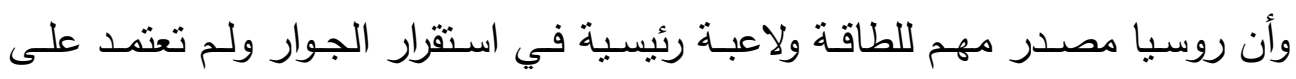

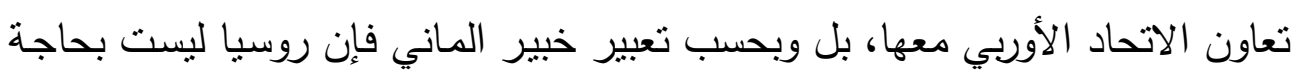

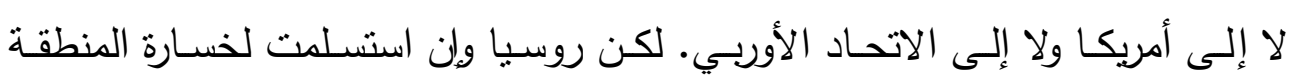

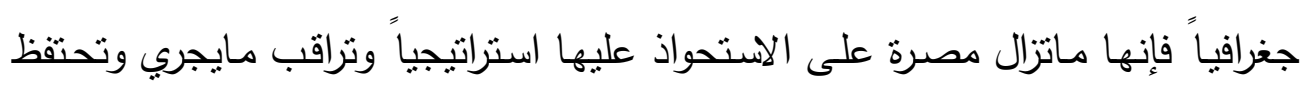

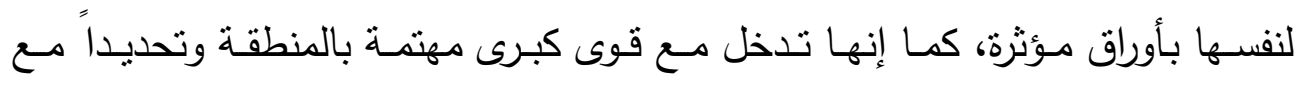

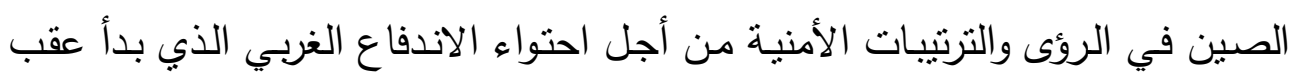
نهاية الحرب الباردة(50).

وفيما يتعلق بالعلاقات الاقتصادية والتعاون المشترك بين المانيا وتركيا، فقد المداديا

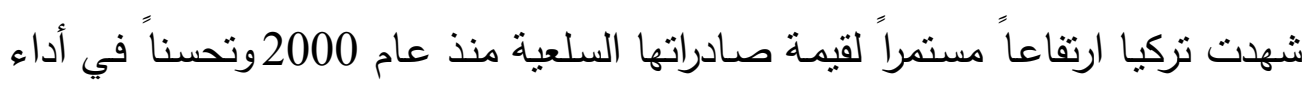

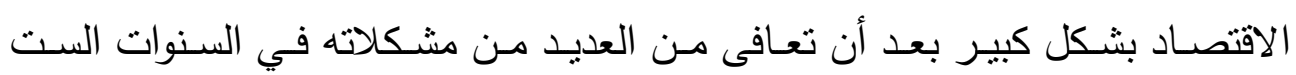


8\% الماضية، حيث تراجعت نسبة التضخم التي بلغت عام 2000 نسبة 55\% لتهبط إلى

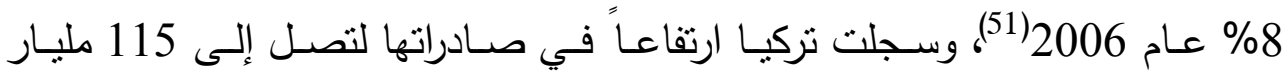
دولار عام 2005، وبلغت حتى منتصف عام 2008 إلى 120 مليار و 650 مليون

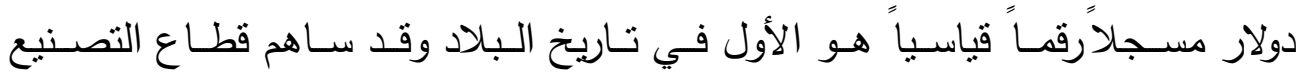

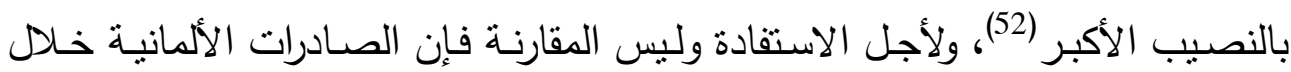
الأثهر النسعة الأولى من عام 2008 بلغت قيمتها 969 مليار يورو ونالت المرتبة الأولى في الصادرات العالمية(53). وسجلت الصادرات الألمانية لتركيا مستوى قياسياً لتبلغ 8.12 مليار يورو عام الترات

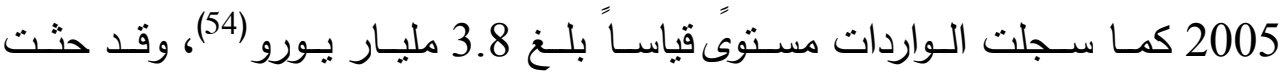
المستشارة الألمانية انجيلا ميركل خلال زيارتها إلى تركيا مطلع ت تلان/2006 الثركات

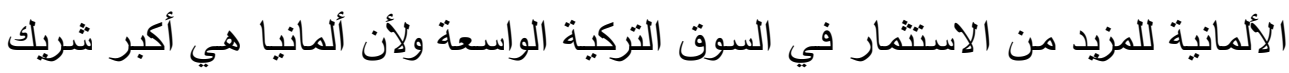
تجاري لتركيا مـع حجم تبادلات تجاريـة تصل إلى نحو 27مليـار دولار سنوياً (55).

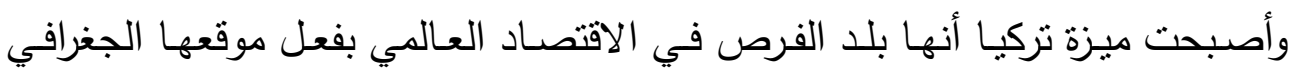

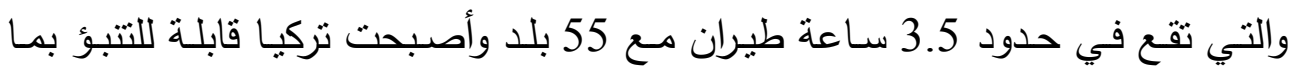

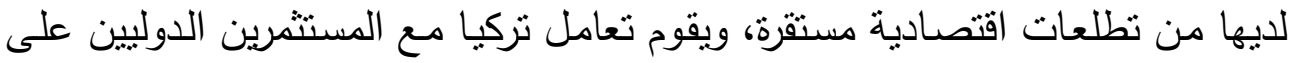

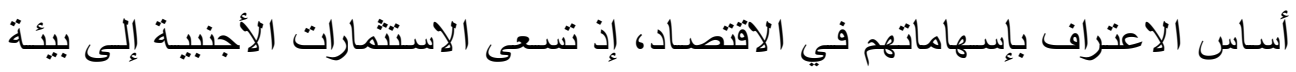

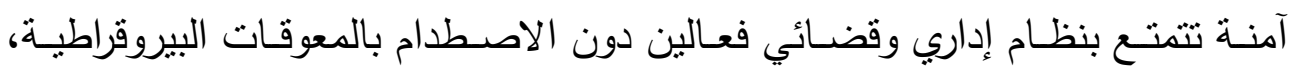

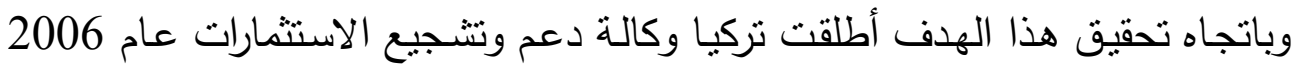
كي تجذب الاستثمارات الأجنبية المباشرة، ولايوجد في تركيا أي فرق بين الاستثمارات

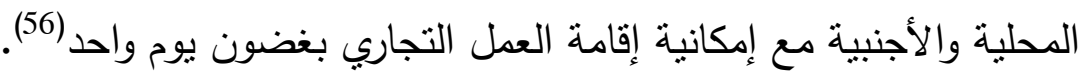
ولأجل المزيد من التعاون بين ألمانيا وتركيا فقد افتتح المستشـار الألماني

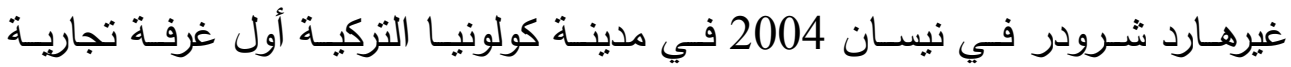

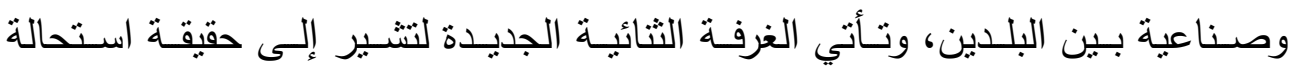

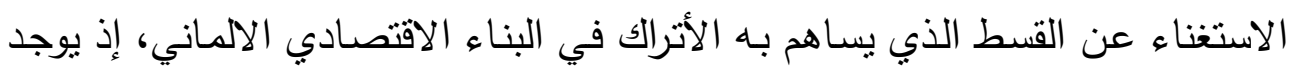

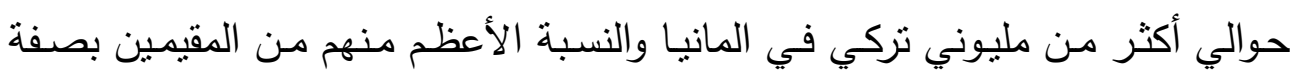


دائمة أو الحاصلين على الجنسية الألمانية، وهؤلاء ليسوا كيدٍ عاملة كما كان عليه

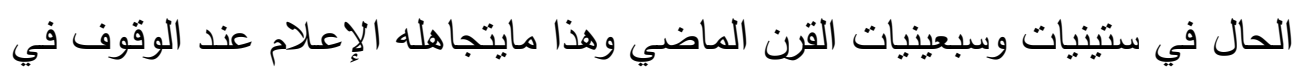

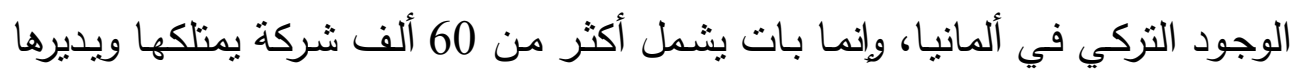

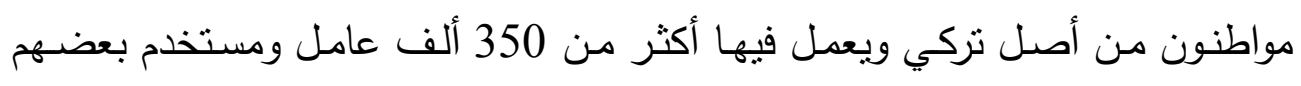

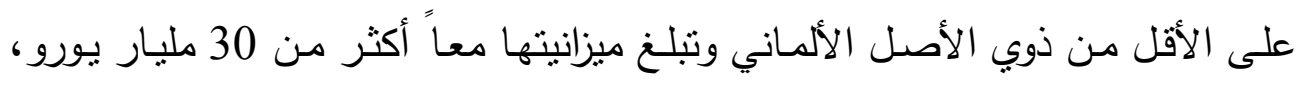

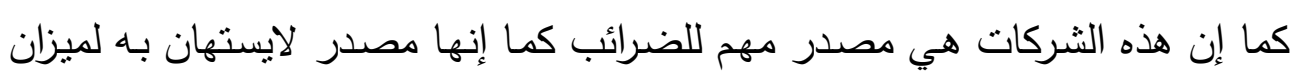

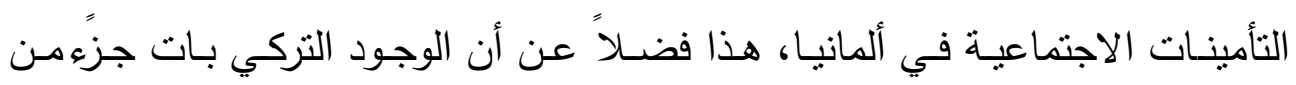

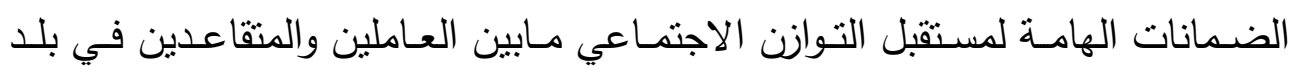

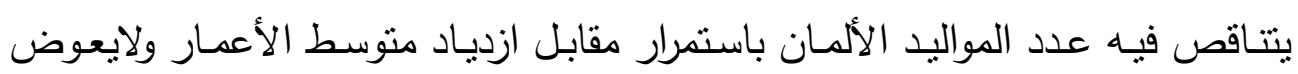
ذللك سوى ارتفاع نسبة المواليد من الأجانب ولاسيما من المسلمين (57).

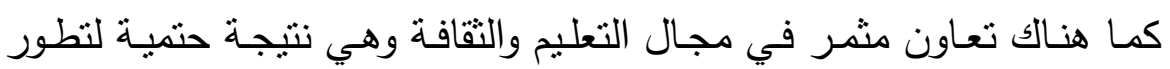

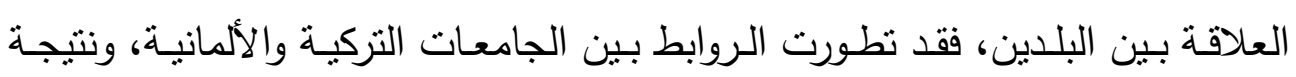

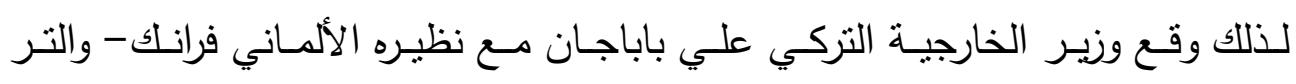

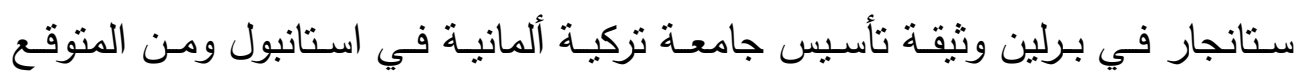

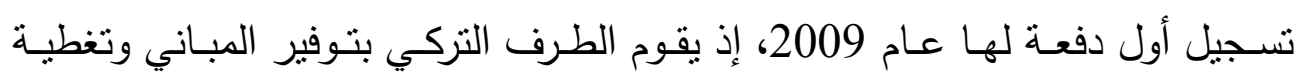

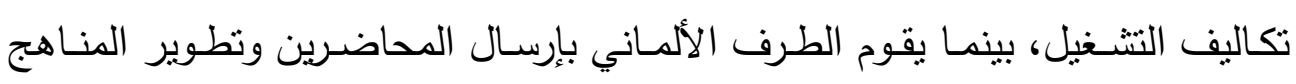

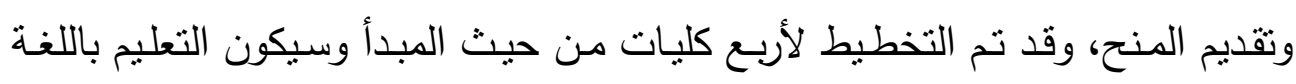

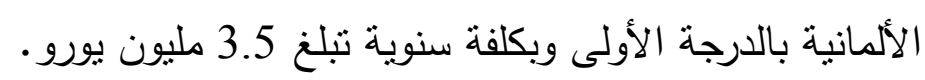

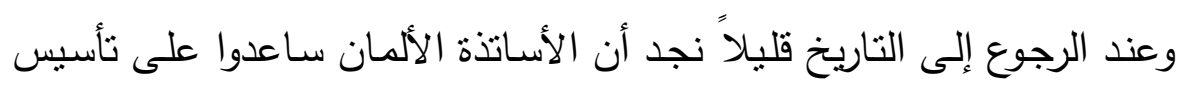

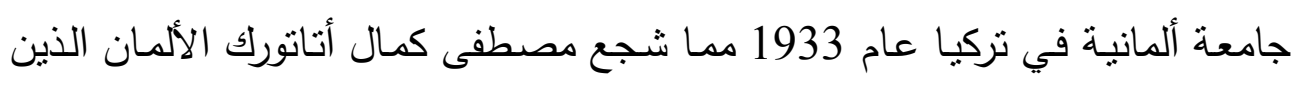

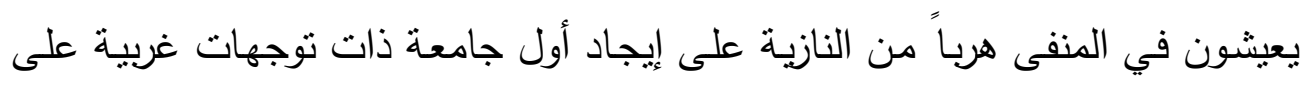
مضيق البسفور (58).

4. الرؤى والمحاور المتأرححة بين البلدين 1- - - القضية الأرمنية: 
تكمن المشكلة في أن الأرمن ثاروا ضد الدولة العثمانيـة عام 1915 بتأييد

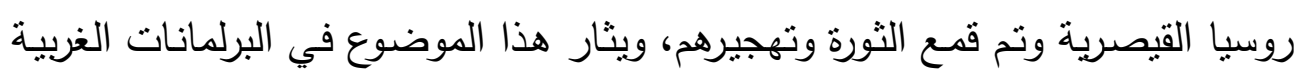

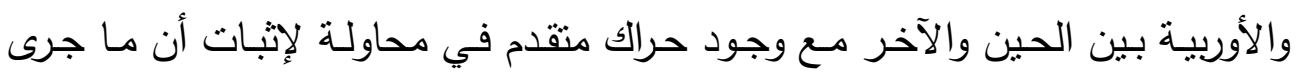

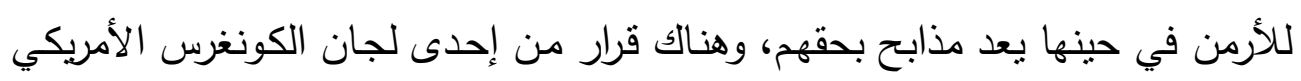

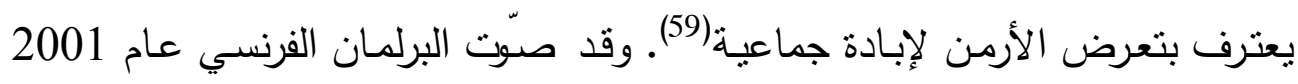

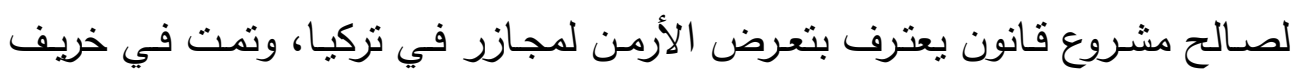

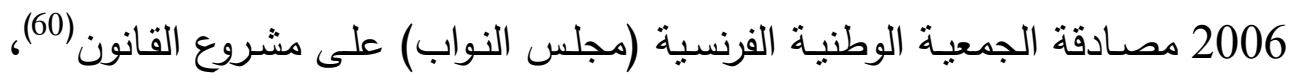

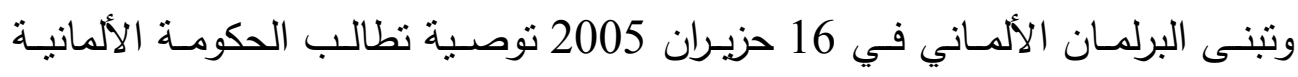
بالضغط على تركيا للنحقيق في أعمال النفي المنظم والتدمير التي تعرض لهان لها الأرمن

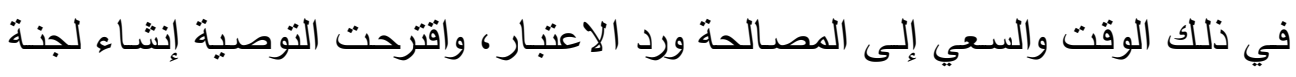

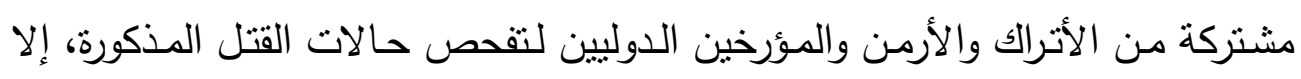

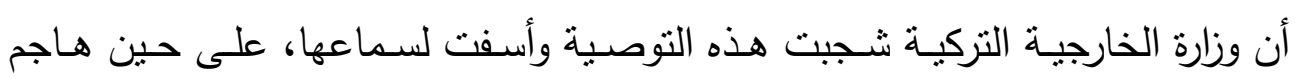
رجب طيب أردوغان رئيس الوزراء التركي هذا القرار واصفاً إياه بالخاطئ جداً والقبيح

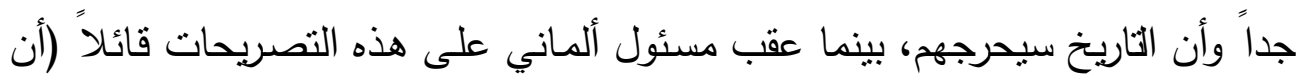

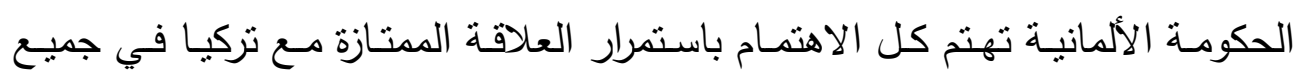

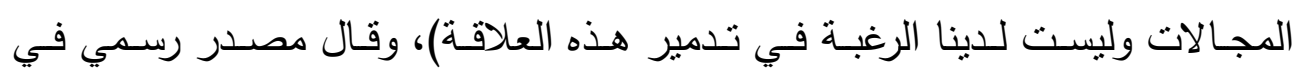

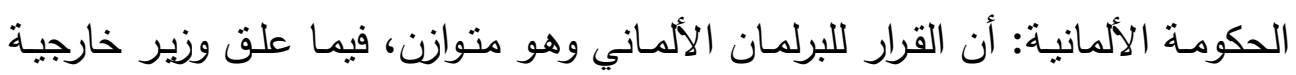

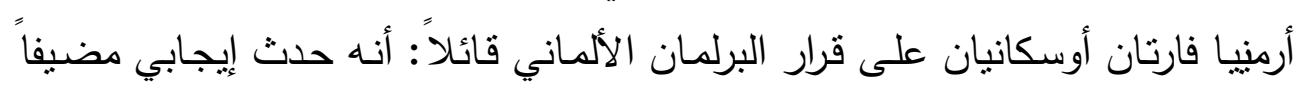

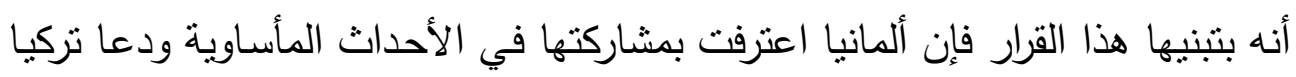

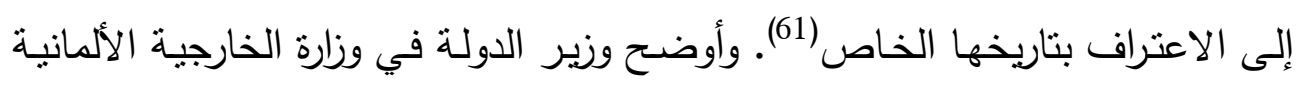
لثؤون أوربا والثرق الأوسط وشمال أفريقيا جونتر جلوسر الثران أمام لجنة الثؤون الخارجية

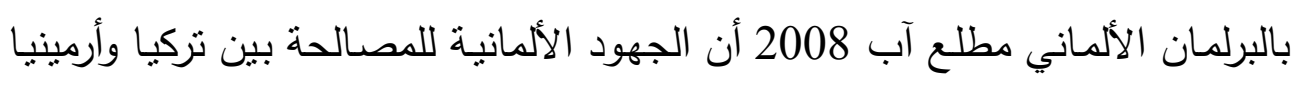

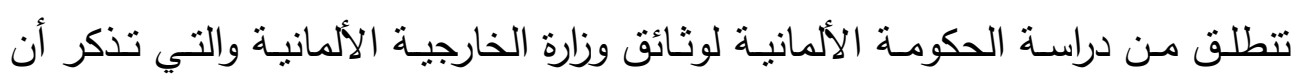

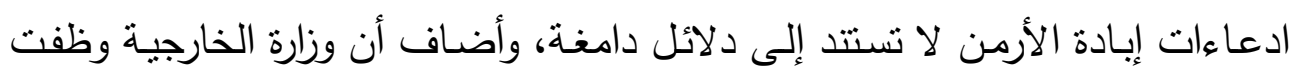
حوالي 300 ألف يورو للحصول على وثائق حول تلك الفترة من مراكز وثائق دولية دانية 
كما أنها تراجع وثائق جامعة مدينة بوتسدام وأن سياسة الثقارب بين أرمينيا وتركيا هي الجيا من أجل التعايش السلمي وتجاوز أحداث الماضي (62).

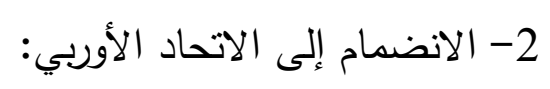

من الحقائق التي تفرض نفسها على الواقع السياسي بين البلدين وجود تيار

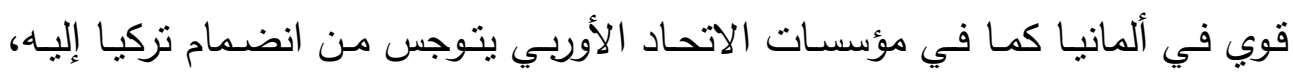

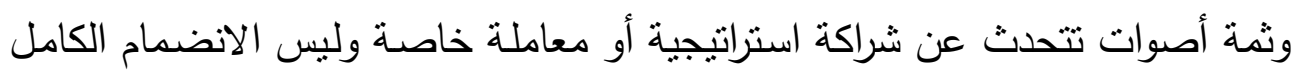

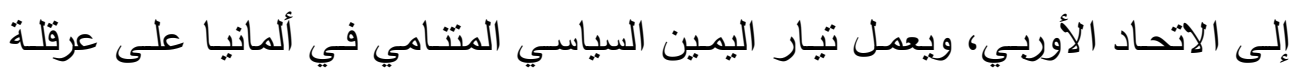

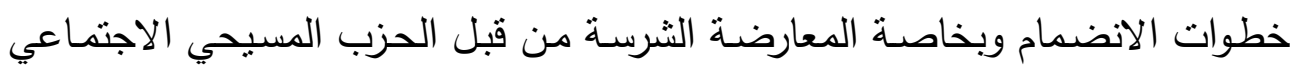

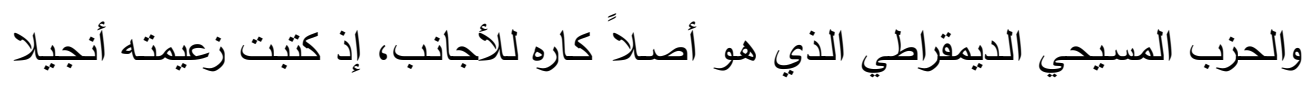

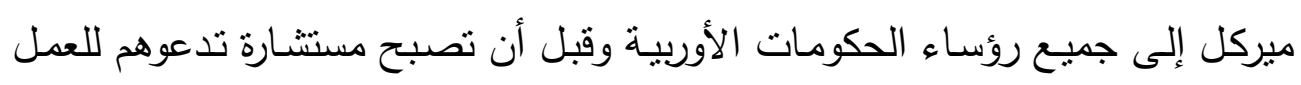

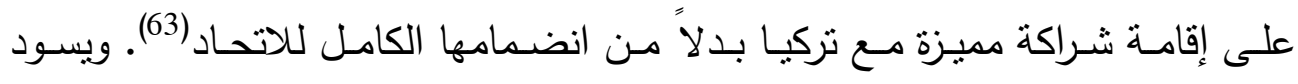

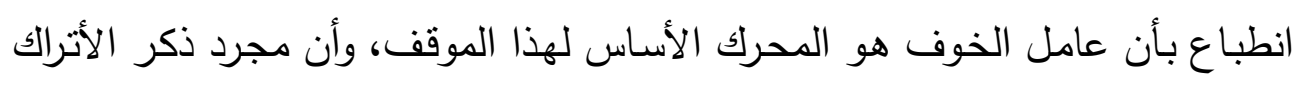

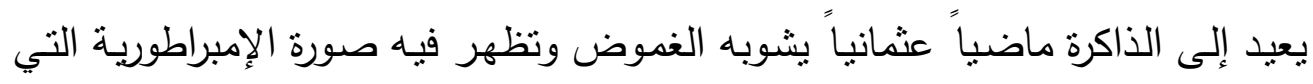

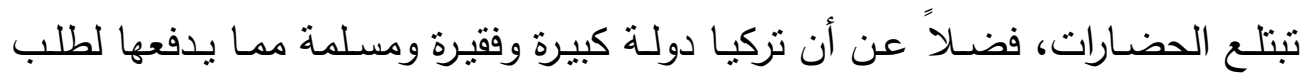

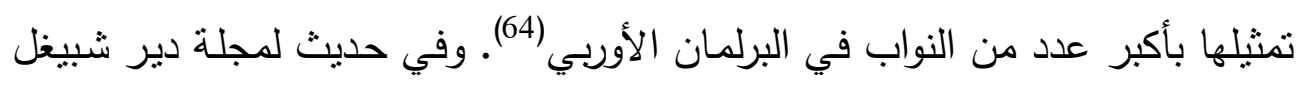

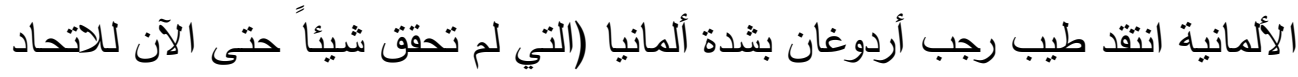

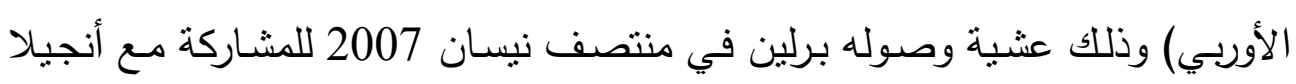

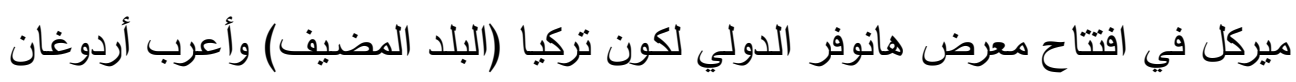

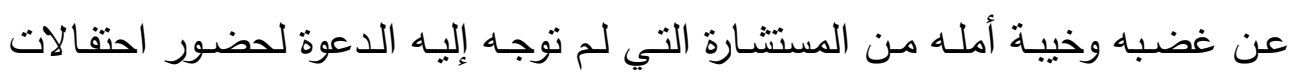

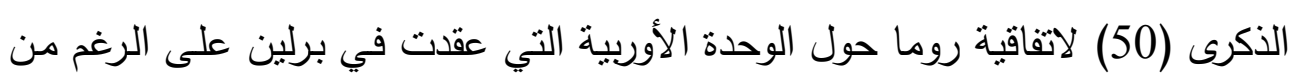

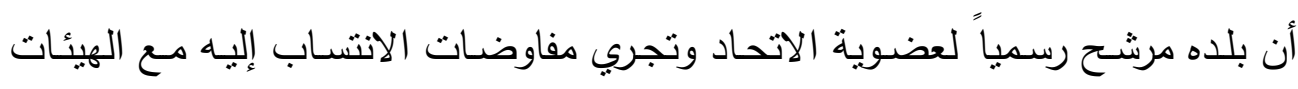

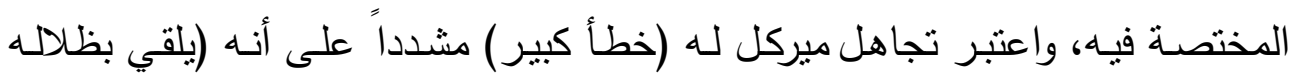

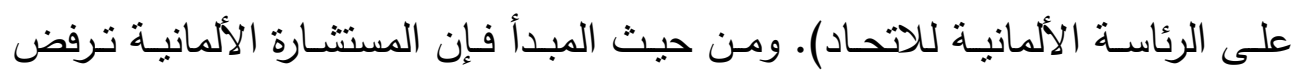

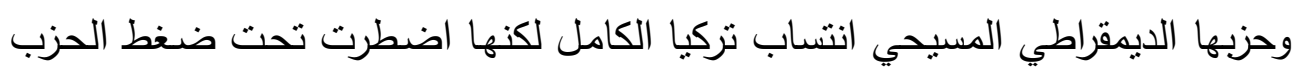


الاشتـراكي الـديمقراطي حليفها في الحكومـة إلى الموافقـة في اعتمـاد قرار الحكومـة

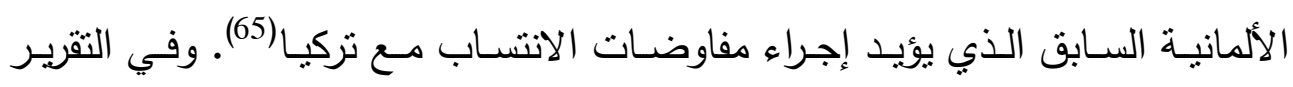

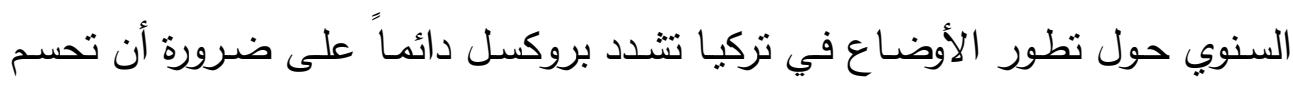
تركيـا أمرهـا مـع العسكر لأن الرقابـة الديمقراطيـة على الجـيش شـكلية كـون القيـادة

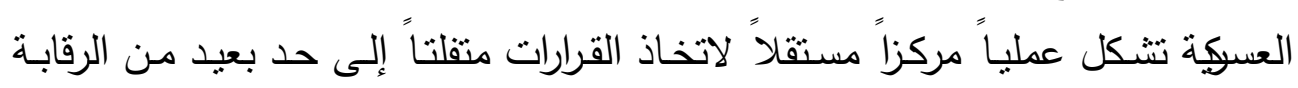
المدنية، وإن كان هناك إصلاح لهذا الجانب فيفترض بـه أن يجعل تبعية قيادة الأركان

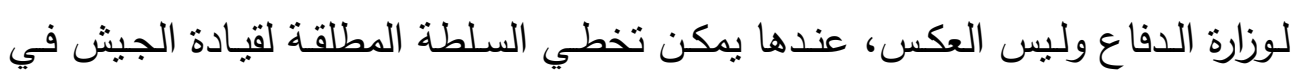
القرارات السياسية والأمنية، وقد يكون هذا الواقع عائقاً رئيساً أمام دخول نركيا الاتحاد الأوربي (66).

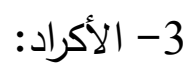

ليس وضـع الأكراد في تركيا مثالياً بأي حال بل هناك حساسية مفرطة إزاء

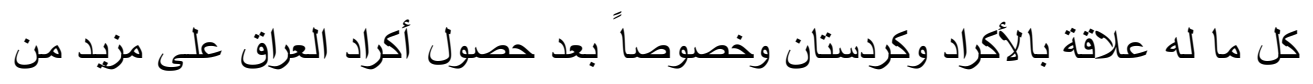

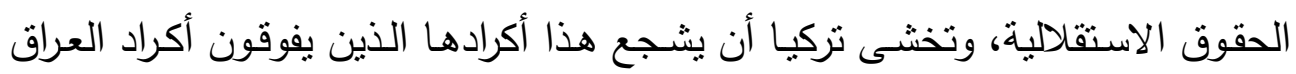

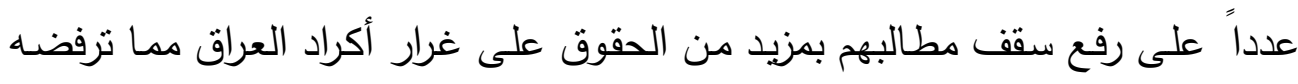
بشدة(67) ومن جانب آخر اتخذ البرلمان الأوربي في ستراسبورغ قراراً في 12 حزبران 1992 حول الأكراد في تركيا جاء فيه (هناك عدم راحة من قبلنا لأن الحكومة التركية لم تتفذ إلى الآن احترام حقوق الإنسان والاعتراف بحقيقة المشكلة الكردية، وبدلاً من

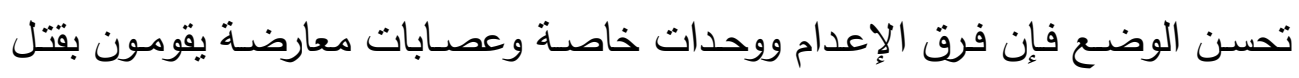
المواطنين... تعد الإجراءات الاقتصـادية والتقافية من الحكومـة التركية لحل المشكلة

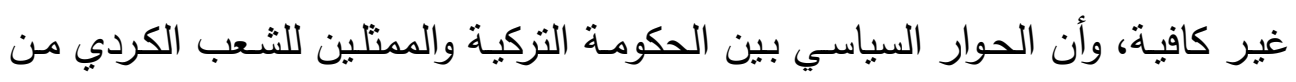

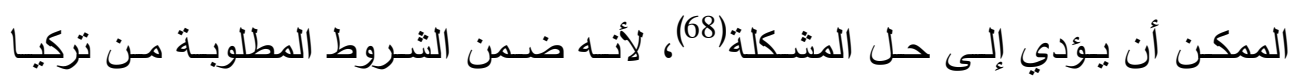
لعضوية الاتحاد الأوربي هو الحرص على حماية حقوق الأقليات بما في ذلك احترام خصوصيتها الثقافية. وشهد النزاع الكردي للتركي تصعيداً عسكرياً منذ خريف 2007

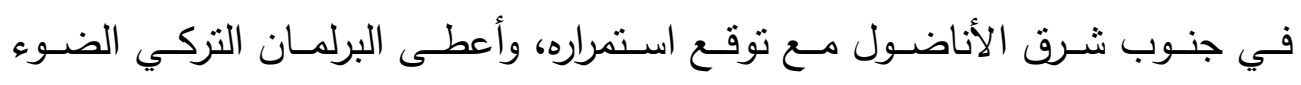




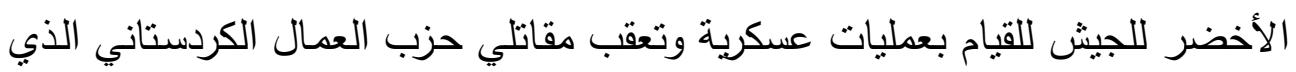

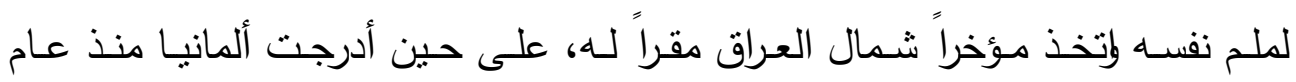

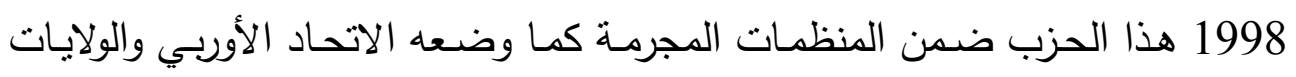

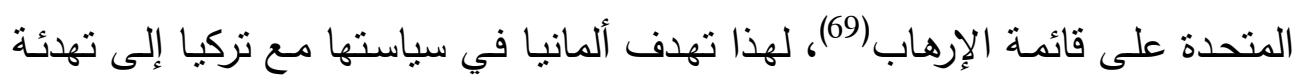

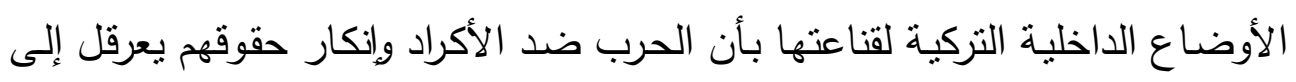

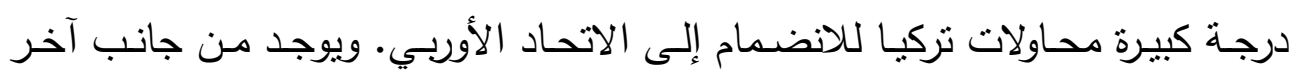

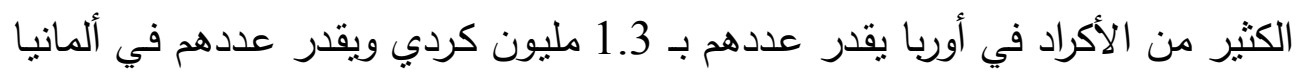
وحدها بـ 600 ألف حصل بعضهم على الجنسية الألمانية وهناك جيل ثالث منهم (70).

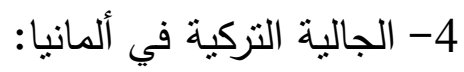

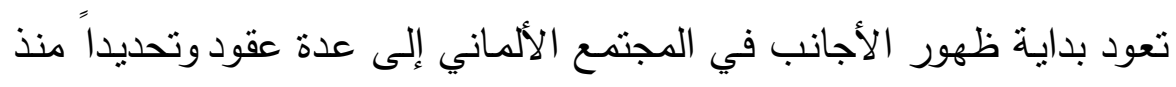

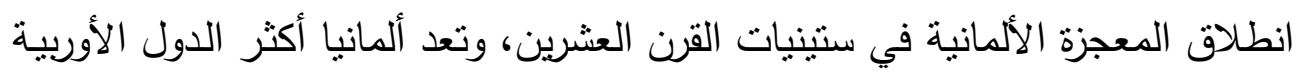

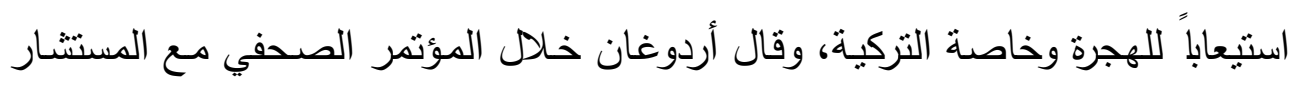

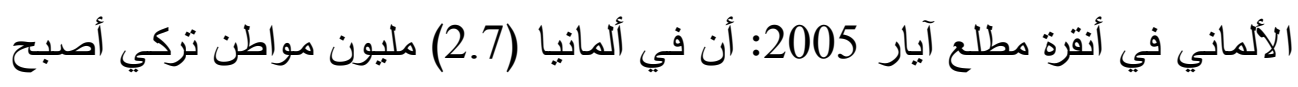

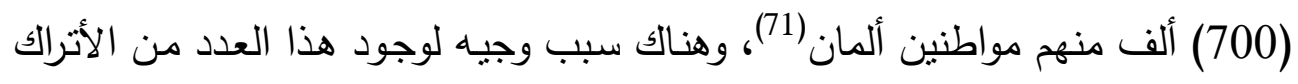
في ألمانيا إضـافة إلى الأسباب المادية وهو أن المهاجر التركي يسنطيع المحافظة المانة

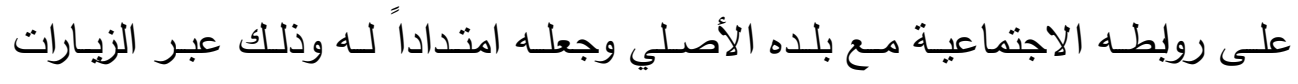

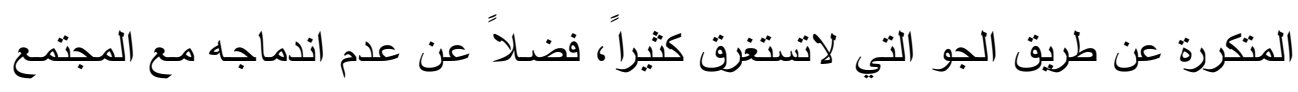

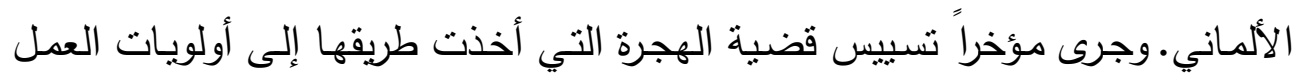

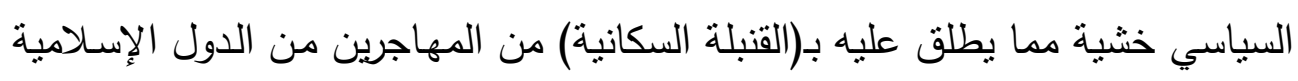

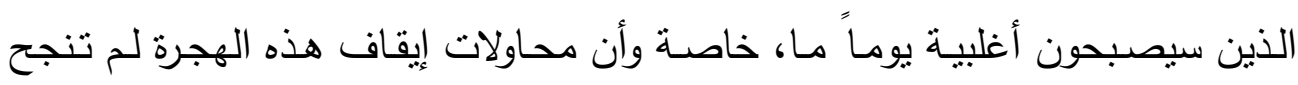

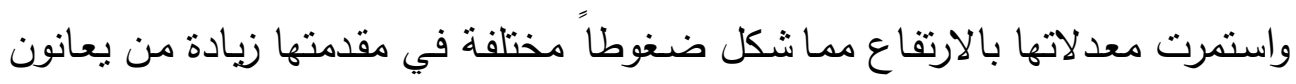

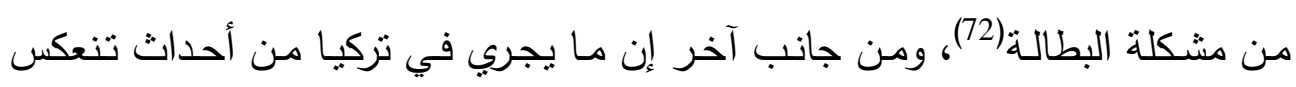

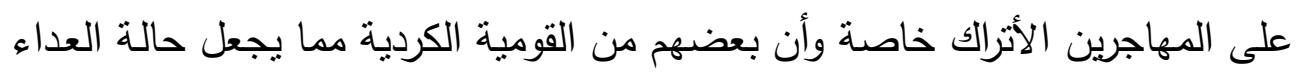
والاحتكاك بينهم منوقعة بما يعكس صورة الداخل النركي ولكن في بيئة ديمقراطية 


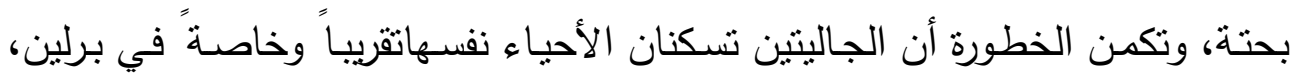

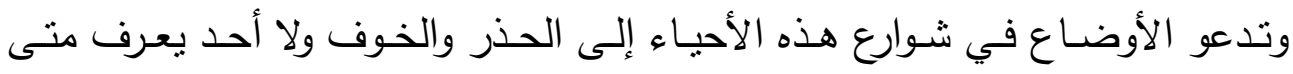

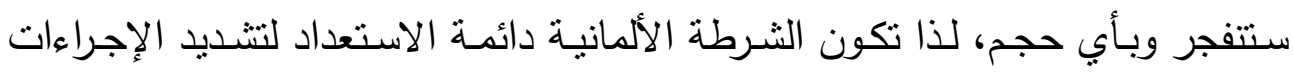

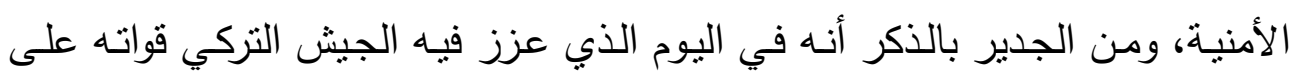

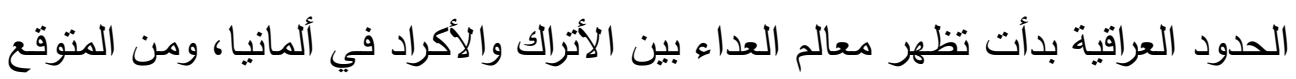

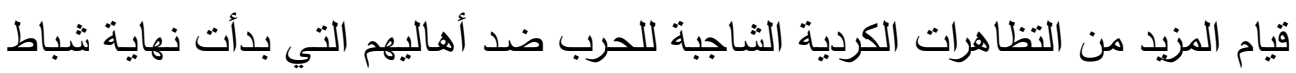

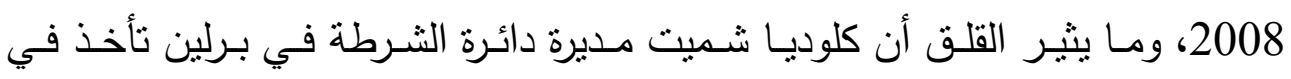

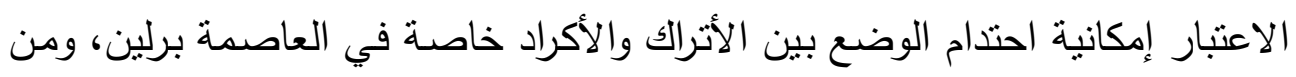

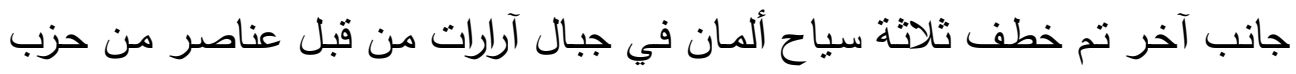

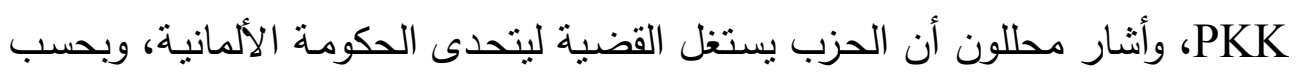

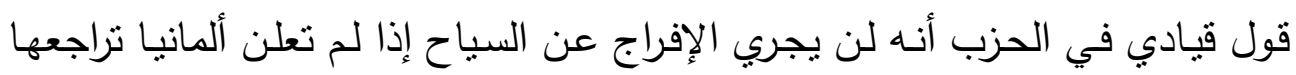

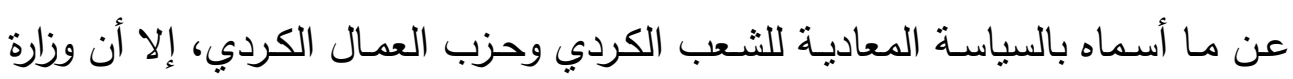

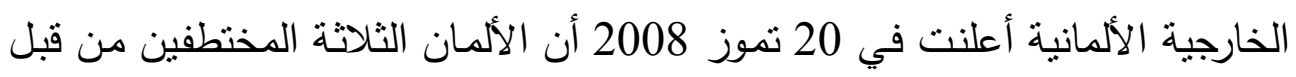

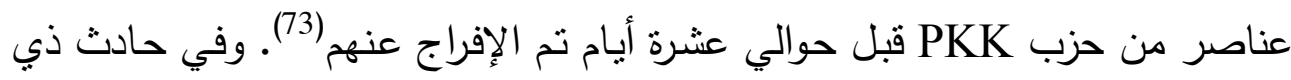

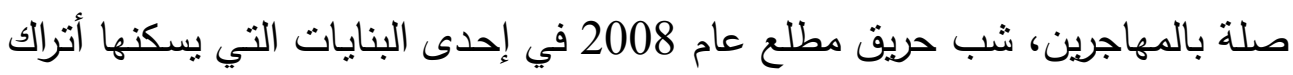

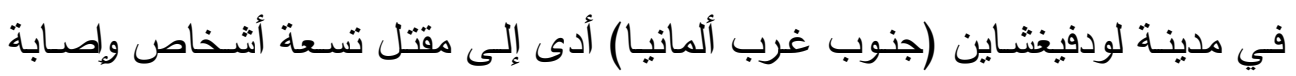

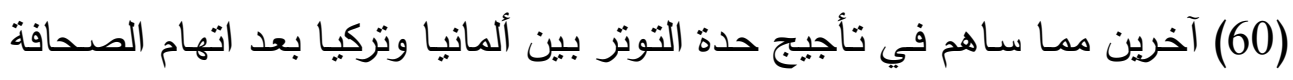

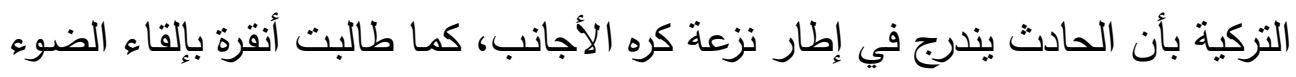

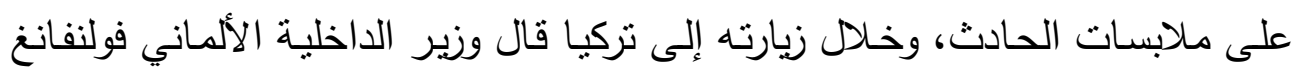

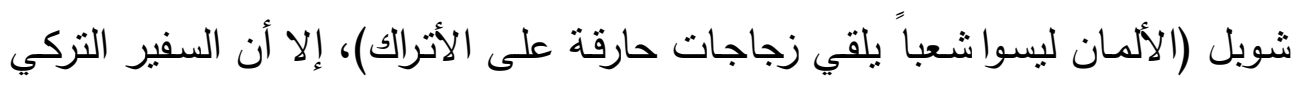

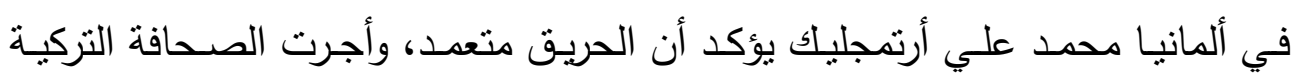

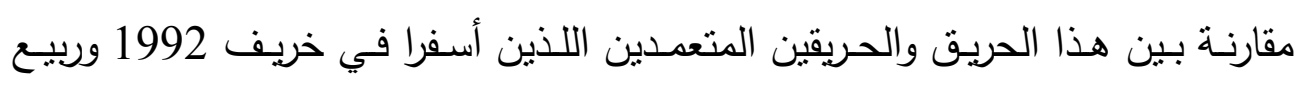
1993 عن مصرع نساء وفتيات تركيات في مولن وزولينغن (غرب ألمانيا) وما يزال

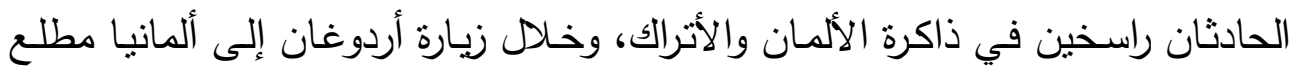

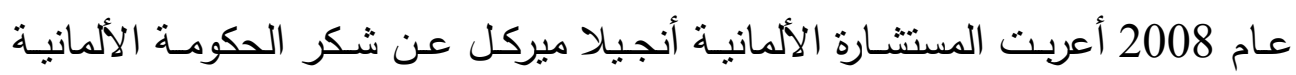


أردوغان لحثه الجالية التركية في ألمانيا على الهدوء جراء الحريق ومطالبته الثباب

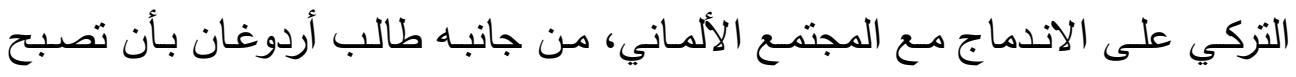

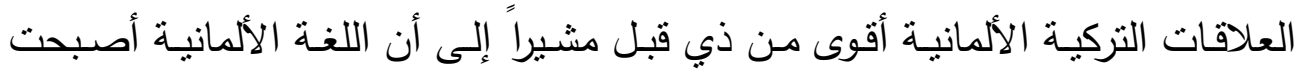
الثالثة في الجامعات والمدارس التركية(74).

\section{خاتمة واستنتاج}

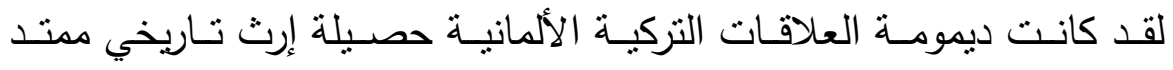

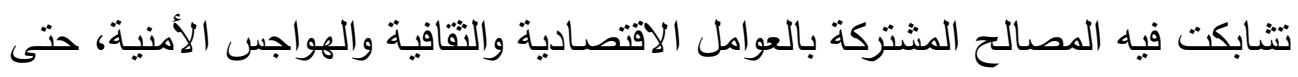

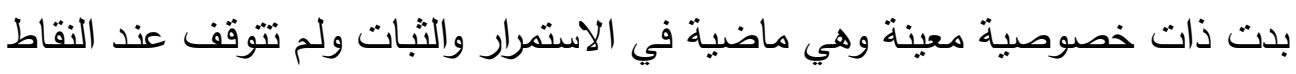

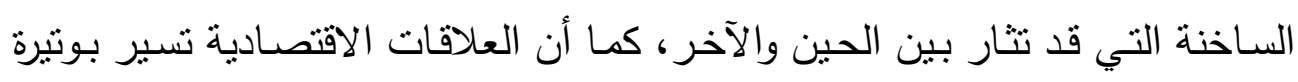

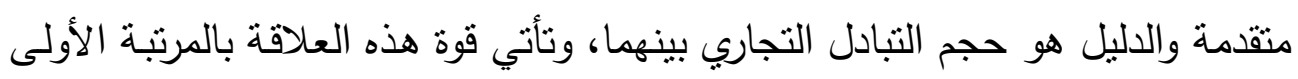

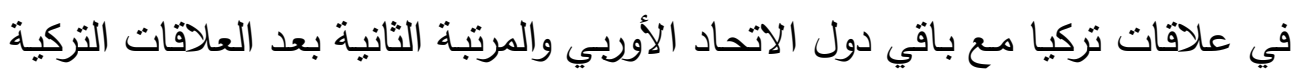

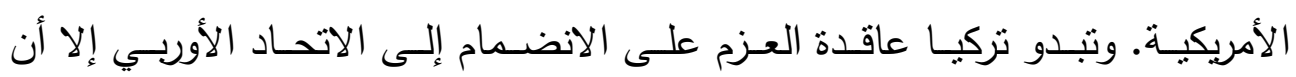

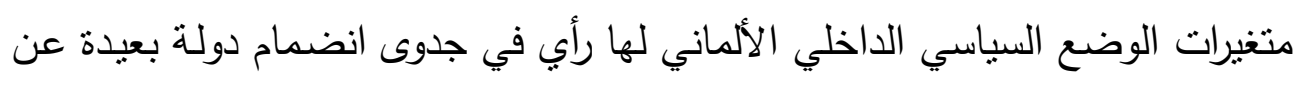

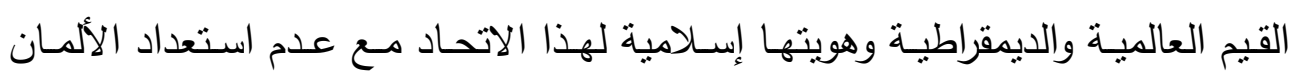

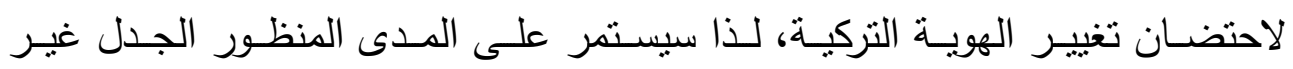

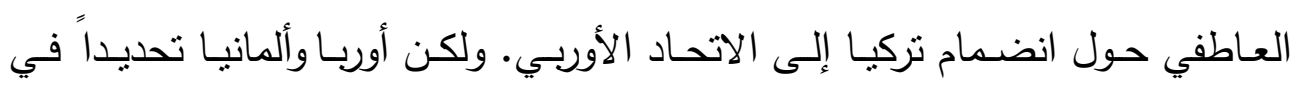

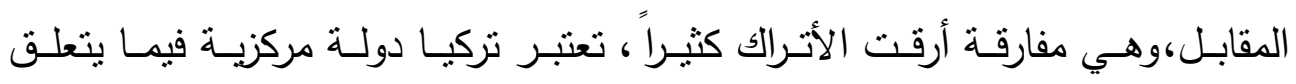

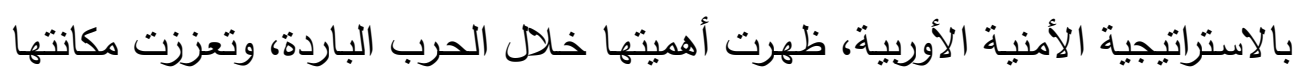

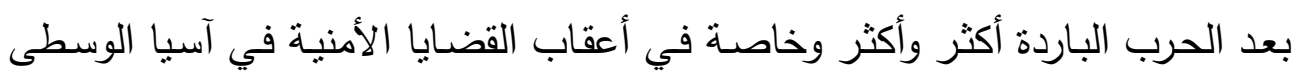

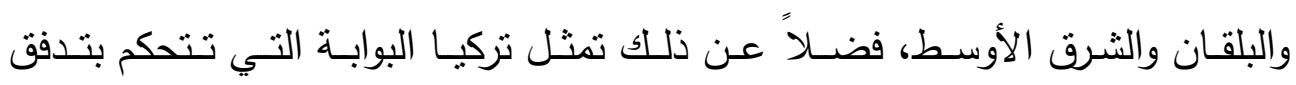
المهاجرين الثرعيين وغير الثرعيين من أقطار عديدة إلى أوربا، وبالتالي فإن إبقاء

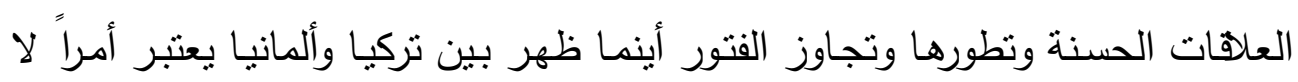

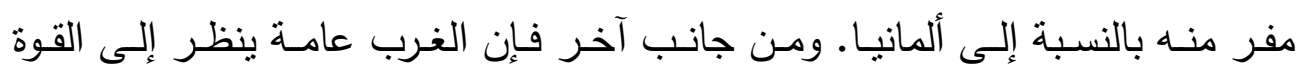

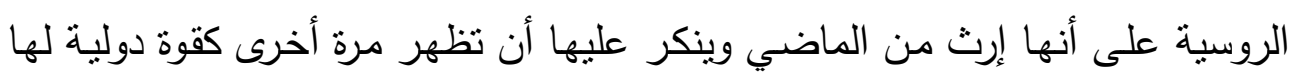




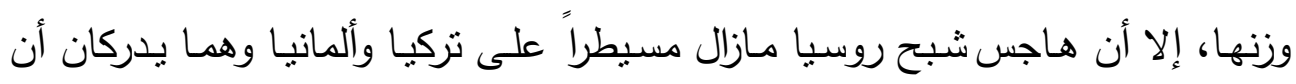

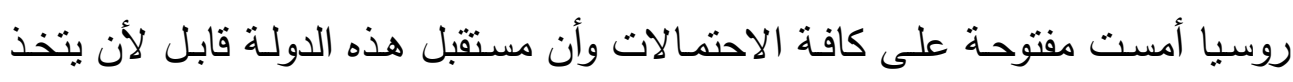

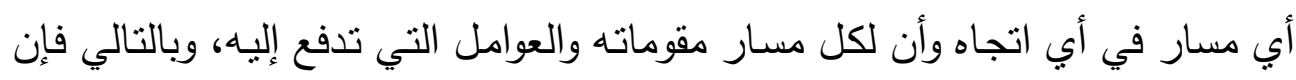
علاقتهما معاً أو منفردتين اتجاه روسيا تصب في اتجاه هذا الإدراك. 


\section{الهوامش}

1 محمد جواد علي، العراق والهند، مجلة دراسات استراتيجية، مركز الدراسات الدولية، جامعة بغداد،

$$
\text { 2 العدد الثالث، 1997، صيشال فيريه، شبكة المعلومات الدولية: }
$$

http://www.mondiploar.com

3 Ulrich Trumpener, Germany and Ottoman Empire 1914-1918, (New Jersey, 1968), P.13

$$
\text { 4 } 5 \text { ميثال فيريه، مصدر سابق. }
$$

6 هنـري لـورنس، اللعبـة الكبـرى (الثــرق العربـي المعاصـر والصـراعات الدوليـة)، ترجمـة: محمــ مخلوف، دار قرطبة للنشر ، قبرص، 1992، ص22.

7 ناظم عبد الواحد الجاسور، قمة مؤتمر الأمن والتعاون الأوربي في استانبول: ميثاق الأمن الأوبي للقرن الحادي والعشرين، دوريـة محطات استراتيجية، مركز الدراسـات الدولية، جامعـة بغداد، العدد

$$
\text { (15) }
$$

8 توسع الناتو إلى شرف أوربا، نرجمة: سميرة عبد الرحمن، سلسلة دراسات منرجمة، مركز الدراسات

$$
\text { الدولية، جامعة بغداد، (بلا سنة)، ص12. }
$$

9 محمد فريد عجاج، القوى الدولية في مطلع القرن الحادي والعشرين، مجلة الدفاع المصرية، العدد

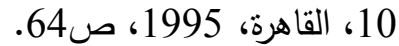

$$
10 \text { جريدة القاصد، العراق، عدد 58، 2005/3/14. }
$$

11

12 هاينز كرامر ، نركيا كقوة إقليمية جديدة، مجلة شؤون الأوسط، بيروت، العدد 55، 1996، ص99.

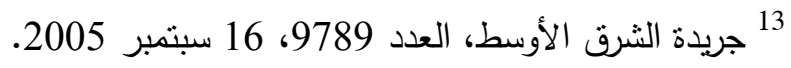

14

http://www.islamonline.net/Arabic/

15 Relations with Germany, Turkish Press, August 27, 2005.

16 ميشال فيربه، مصدر سابق.

17 ستنفن جي. فلانانغات، تركيا والغرب على مفترق الطرق الاستراتيجية، ترجمة: سميرة إبراهيم، المرصد الدولي، مركز الدراسات الدولية، جامعة بغداد، العدد الخامس، 2007، ص116. 


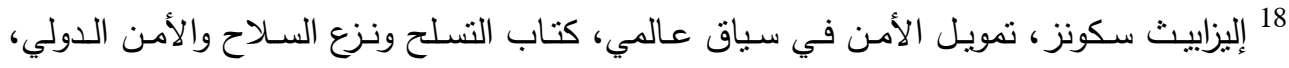
(الكتاب السنوي 2005)، ترجمة: حسن حسن وعمر الأيوبي، مركز دراسات الوحدة العربية، بيروت،

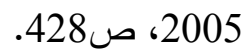
19

http://www.akhbaralaalam.net/news

20 هاينز كرامر ، نركيا المتغيرة؛ تبحث عن ثوب جديد، تعريب: فاضل جنكر، مكتبـة العبيكان،

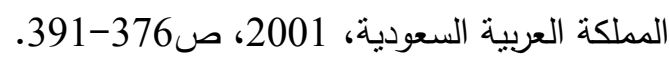
21 ناظم عبد الواحد الجاسور ، ألمانيا الموحدة والقرن القادم: محددات القوة الإقليمية والدولية، دورية

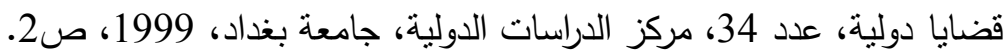

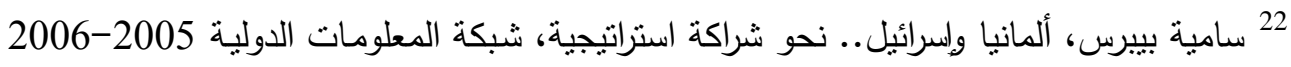
http://www.siyassa.org.cg/

23 وزير خارجية ألمانيا في كتاب جديد حول الثرق الأوسط بعد غزو العراق، جريدة الأهرام، العدد/

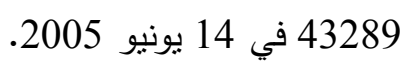

24 القوة والحق وما بينهما (افتتاحية المجلة)، مجلة شؤون الأوسط، بيروت، العدد 1213289، 2006، ص.25 (n 25 محمد سـعيد أبو عـامود، العلاقات الأوربيـة-العربيـة: رؤيـة مستقبلية، مجلـة السياسـة الدوليـة،

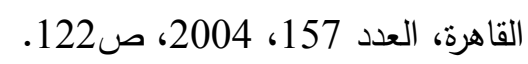

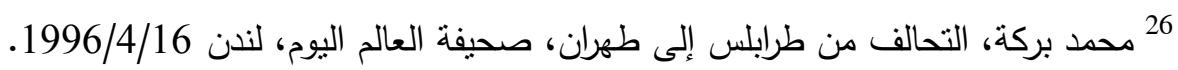

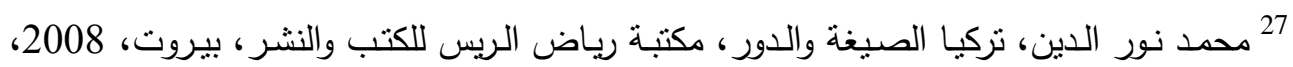

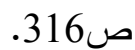
28 عبد العظيم محمود حنفي، اتجاهات جديدة في السياسة الخارجية التركية، مجلة السياسة الدولية،

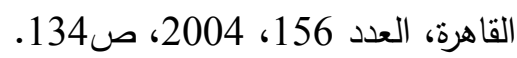
29 نجوى عبد المعبود الأشول، العلاقات الأوربية-لأمريكية: بين الاستقلال والتبعية، مجلة السياسة

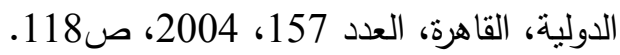
30 المصدر نفسه، ص117.

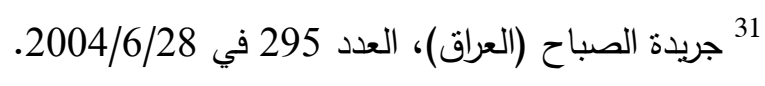
32

http://www.akhbaralaalam.net/news.

33 محمد نور الدين، الديمقراطية التركية.أمام امتحان جديد، جريدة الثرق القطرية 2003/6/22. 
http://www.akhbaralaalam.net.news.

35 ماللك مفتي، الجرأة والحذر في سياسة تركيا الخارجية، دراسات عالمية، مركز الإمارات للاراسات

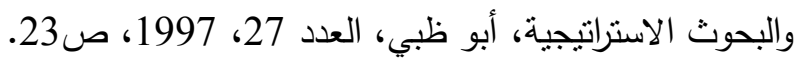

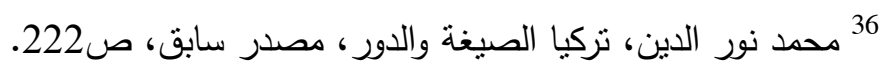

$$
\begin{aligned}
& 37 \text { تتامي العلاقات الأرمنية التركية، شبكة المعلومات الدولية: }
\end{aligned}
$$

http://www.akhbaralaalam.net/news.

38 تركيا متفائلة بقرب إطلاق مفاوضات شاملة لحل الأزمة في قبرص، شبكة المعلومات الدولية: http://www.akhbaralaalam.net/news.

39 أنقرة نأمل دعم برلين لانضمامها للاتحاد الأوربي، شبكة المعلومات الدولية: http://www.aljazeera.net/news.

40 استئناف المفاوضات بين سوريا واسرائيل في أنقرة، شبكة المعلومات الدولية: http://ar.timeturk.com/news.

$$
41
$$

http://www.al-akhbar.com/ar.

42 نزكيـا: إيـران والـدول السـت تطلب وسـاطنتا لــل أزمــة النـووي، شـبكة المعلومـات الدوليـة: http://ar.timeturk.com/news.

$$
\text { 43 } 43
$$

http://www.aljeeran.net.

44 تزكيا تتنهج موقفاً حذراً بشأن العلاقات مع إيران، شبكة المعلومات الدولية: http://ar.timeturk.com/news.

$$
45
$$

http://www.assabeel.net/main.

$$
46 \text { تركيا وروسيا تبحثان إقامة تحالف بين دول القوقاز ، شبكة المعلومات الدولية: }
$$

http://www.akhbaralaalam.net/news.

$$
47 \text { روسيا تقدر جهود نركيا في حل قضية القوقاز ، شبكة المعلومات الدولية: }
$$

http://www.akhbaralaalam.net/news.

$$
48 \text { نزع فتيل حرب محتملة بين روسيا وتركيا، شبكة المعومات الدولية: }
$$

http://www.akhbaralaalam.net/news.

49 ميركل تعد بانضمام جورجيا إلى الناتو، شبكة المعلومات الدولية: http://ar.timeturk.com/news.

إبراهيم عرفان، آسيا الوسطى.. التتافس الدولي في منطقة مغلقة، السياسة الدولية، القاهرة، العدد 


$$
\text { 51 } 51
$$

52 الصادرات التركية تضرب الرقم القياسي هذا العام، شبكة المعلومات الدولية: http://ar.timeturk.com/news.

ألمانيا الأولى عالمياً في قائمة الدول المصدرة، شبكة المعلومات الدولية: http://us.moheet.com/

54 أهم شريك اقتصادي لألمانيا في الشرق الأوسط، شبكة المعلومات الدولية: http://www.dw-world.de 55 ميركل تحبط آمال تركيا الأوربية، شبكة المعلومات الدولية: http://www.alhourriah.org

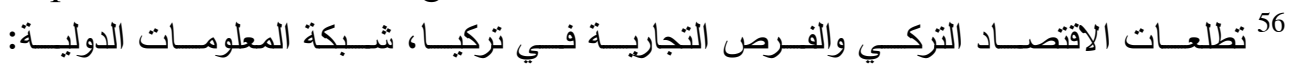
http://www.akhbaralaalam.net/news.

57 تعزيز الأمن الأوربي بتجربة أردوغان، شبكة المعلومات الدولية: http://www.islamonline.net/Arabic/

$$
58 \text { منارة أكاديمية على مضيق البوسفور ، جريدة الغد، 2008/6/16. }
$$

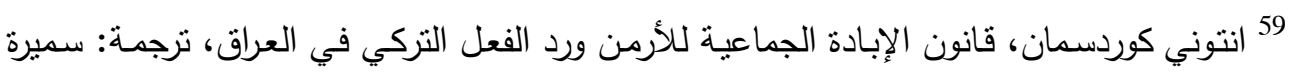

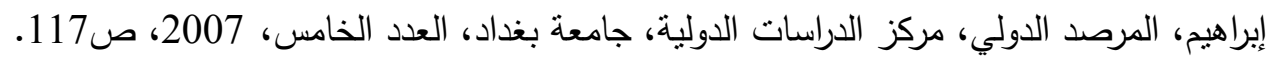

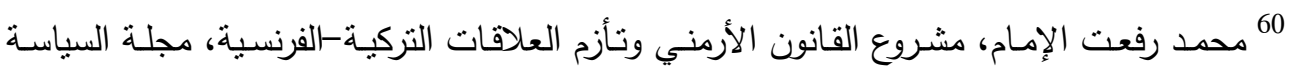

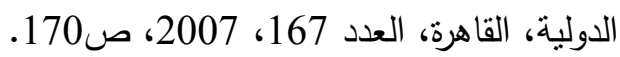
61 البرلمان الألماني يدعو الحكومة التركية للنحقيق في الإبادة الأرمنية، شبكة المعلومات الدولية: http://ara-ashiian.blogsnot.com.

62 وساطة ألمانية بين نركيا وأرمينيا، شبكة المعلومات الدولية: http://ar.timeturk.com/news.

63 تركيا: طريق شائك نحو الاتحاد الأوربي، شبكة المعلومات الدولية: http://www.ecssr.ac.ae/CDA/

$$
64 \text { ملحق جريدة الحياة (الوسط)، العدد } 64 \text { الحريدة الحياة، } 648 \text { في 2007/4/16. }
$$

http://www.mondiploar.com

67 الخلافات التركية-الكردية، شبكة المعلومات الدولية:

http://news.bbc.co.uk.

68 أحمد نوري النعيمي، القضية الكردية في تركيا: الواقع والمستقبل، مجلة دراسات دولية، مركز الدراسات الدولية، جامعة بغداد، العدد 48، 2003، ص58. 
69 ألمانبا بين السندان التركي والمطرقة الكردية، شبكة المعلومات الدولية: http://www.akhbaralaalam.net/news.

70 على خلفيـة النـوتر الثركي الكـردي ألمانيـا تتحضـر لأي تصـعيد، شـبكة المعلومـات الدوليـة: http://www.gemyakurda.net.

71 فناة الجزيرة الفضائية، 2005/5/7.

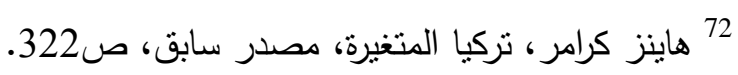

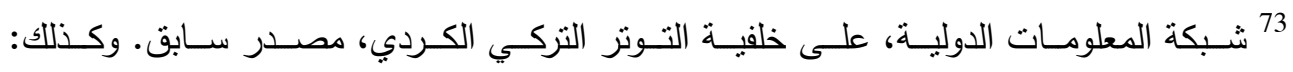
http://www.akhbaralaalam.net/news.

74 حريق متعمد يؤجج التوتر بين الألمان والأتراك، شبكة المعلومات الدولية: http://afp.google.com/

وكذلك:

http://www.fananews.com 